\title{
The kinetics of the olivine dissolution under the extreme conditions of nano-silica production
}

Citation for published version (APA):

Lazaro, A., Benac-Vegas, L., Brouwers, H. J. H., Geus, J. W., \& Bastida, J. (2015). The kinetics of the olivine dissolution under the extreme conditions of nano-silica production. Applied Geochemistry, 52(1), 1-15. https://doi.org/10.1016/j.apgeochem.2014.10.015

\section{Document license:}

TAVERNE

DOI:

10.1016/j.apgeochem.2014.10.015

Document status and date:

Published: 01/01/2015

\section{Document Version:}

Publisher's PDF, also known as Version of Record (includes final page, issue and volume numbers)

\section{Please check the document version of this publication:}

- A submitted manuscript is the version of the article upon submission and before peer-review. There can be important differences between the submitted version and the official published version of record. People interested in the research are advised to contact the author for the final version of the publication, or visit the $\mathrm{DOI}$ to the publisher's website.

- The final author version and the galley proof are versions of the publication after peer review.

- The final published version features the final layout of the paper including the volume, issue and page numbers.

Link to publication

\section{General rights}

Copyright and moral rights for the publications made accessible in the public portal are retained by the authors and/or other copyright owners and it is a condition of accessing publications that users recognise and abide by the legal requirements associated with these rights.

- Users may download and print one copy of any publication from the public portal for the purpose of private study or research.

- You may not further distribute the material or use it for any profit-making activity or commercial gain

- You may freely distribute the URL identifying the publication in the public portal.

If the publication is distributed under the terms of Article 25fa of the Dutch Copyright Act, indicated by the "Taverne" license above, please follow below link for the End User Agreement:

www.tue.nl/taverne

Take down policy

If you believe that this document breaches copyright please contact us at:

openaccess@tue.nl

providing details and we will investigate your claim. 


\title{
The kinetics of the olivine dissolution under the extreme conditions of nano-silica production
}

\author{
A. Lazaro ${ }^{a, *}$, L. Benac-Vegas ${ }^{b}$, H.J.H. Brouwers ${ }^{a}$, J.W. Geus ${ }^{c}$, J. Bastida ${ }^{d}$ \\ a Department of the Built Environment, Eindhoven University of Technology, P.O. Box 513, 5600 MB Eindhoven, The Netherlands \\ ${ }^{\mathrm{b}}$ Technical Department of Wastewater Treatment Technologies, Red Control, Paterna, Spain \\ ${ }^{\mathrm{c}}$ Debye Institute for Nanomaterials Science, University of Utrecht, Utrecht, The Netherlands \\ ${ }^{\mathrm{d}}$ Department of Geology, Universitat de Valencia, Spain
}

\section{A R T I C L E I N F O}

\section{Article history:}

Available online 30 October 2014

Editorial handling by M. Kersten

\begin{abstract}
A B S T R A C T
This article addresses the kinetics of the dissolution of olivine for nano-silica production at extreme conditions. The extreme conditions are $\mathrm{pH}$ values between -0.7 and 1 , temperature between 50 and $90{ }^{\circ} \mathrm{C}$, solid content around $250 \mathrm{~g} / \mathrm{L}$ and percentage dissolved between $80 \%$ and $99 \%$. This work is structured in 3 parts: (1) chemical and mineralogical characterization of the dunites employed; (2) mechanism of the olivine dissolution focusing on the possible resistances to the transport; and (3) determination of the kinetic parameters $k_{T}$ and $n$.

The results shown here demonstrate that: (1) the limiting step of this process is not the diffusion through a silica layer but the surface reaction; and (2) the dissolution of olivine under the olivine nano-silica production conditions is well described by:

$r=A \cdot \exp \left(\frac{-E_{a}}{R \cdot T}\right) \cdot a_{\mathrm{H}^{+}}^{n}=856 \cdot \exp \left(\frac{-78.5}{R \cdot T}\right) \cdot a_{\mathrm{H}^{+}}^{0.5}$,

where $r$ is the dissolution rate $\left(\mathrm{mol} \mathrm{cm}^{-2} \mathrm{~s}^{-1}\right), A$ the pre-exponential factor $\left(\mathrm{mol} \mathrm{cm}^{-2} \mathrm{~s}^{-1}\right)$, $E_{a}$ the activation energy $(\mathrm{kJ} / \mathrm{mol}), R$ the gas constant $\left(8.314 \cdot 10^{-3} \mathrm{~kJ} \mathrm{~mol}^{-1} \mathrm{~K}^{-1}\right), T$ the temperature $(\mathrm{K}), a_{\mathrm{H}}^{+}$the hydrogen ion activity and $n$ the reaction order. The average error of the reaction rate calculated using these parameters is $5.5 \%$ for dunite CRS-US. In addition, this model is successfully applied to the dissolution of other commercial dunites and for bigger reactor volumes. Therefore, this model can be considered to be robust, and it can be used in the industrial production of olivine nano-silica.
\end{abstract}

(c) 2014 Elsevier Ltd. All rights reserved.

\section{Introduction}

Nano-silica is one of the most used nano-materials; its use is rising $5.6 \%$ per year to reach a projected 2.8 million metric tons in 2016 (Freedonia, 2012). The current production methods, of which the most important are the thermal and wet routes, involve steps with high temperatures (above $1000^{\circ} \mathrm{C}$ ). To establish these temperatures, large amounts of fuel are consumed making these processes: (a) unsustainable because of the increasing scarcity of fuels; (b) environmentally unfriendly because of the considerable amount of $\mathrm{CO}_{2}$ emitted; and (c) expensive because of the fuel's price.

The dissolution of olivine in acid, see Eq. (1), is carried out at low temperatures (between 50 and $95^{\circ} \mathrm{C}$ ) and represents a convenient alternative for producing amorphous silica because olivine is

\footnotetext{
* Corresponding author. Tel.: +31 (0)40 2473411.

E-mail address: a.lazaro.garcia@tue.nl (A. Lazaro).
}

one of the fastest weathering silicates minerals, but also because of the high quality of the silica and the low energy requirements (Jonckbloedt, 1997; Lazaro et al., 2013a) (more information about the properties of olivine nano-silica can be found in (Lazaro et al., 2012, 2013b; Lieftink and Geus, 1998)):

$(\mathrm{Mg}, \mathrm{Fe})_{2} \mathrm{SiO}_{4}+4 \mathrm{H}^{+} \rightarrow \mathrm{Si}(\mathrm{OH})_{4}+2(\mathrm{Mg}, \mathrm{Fe})^{2+}$.

The study of the dissolution of olivine is essential for the largescale production of nano-silica for two reasons: (1) for the industrial production of olivine nano-silica, as for any industrial process, the assessment of the reaction kinetics is needed in order to predict the time required to achieve a desired conversion degree; and (2) the properties of olivine nano-silica (i.e., specific surface area, aggregated/agglomerated state, etc.) depend on the kinetics of the dissolution of olivine (Lazaro et al., 2013b; Lieftink, 1997).

Many researchers have studied the dissolution of olivine under normal weathering conditions (above $\mathrm{pH} \mathrm{1,} \mathrm{a} \mathrm{pure} \mathrm{or} \mathrm{pristine}$ olivine material, a dissolved olivine fraction smaller than $10 \%$ 


\section{Nomenclature}

\begin{tabular}{|c|c|c|c|}
\hline Roman & & $v_{t}$ & free settling velocity $(\mathrm{m} / \mathrm{s})$ \\
\hline$a$ & activity & $\omega$ & mass fraction (\%) \\
\hline$A$ & pre-exponential factor $\left(\mathrm{mol} \mathrm{cm}{ }^{-2} \mathrm{~s}^{-1}\right)$ & $X$ & conversion $(\%)$ \\
\hline$C_{D}$ & drag coefficient & & \\
\hline$d$ & diameter of the particle $(\mu \mathrm{m})$ & Greek & \\
\hline$D$ & diffusion coefficient $\left(\mathrm{m}^{2} / \mathrm{s}\right)$ & $\lambda$ & roughness factor \\
\hline$E_{A}$ & activation energy $(\mathrm{kJ} / \mathrm{mol})$ & $\rho$ & density \\
\hline Fo & forsterite content (\%) & $\mu$ & viscosity \\
\hline$k_{T}$ & rate constant $\left(\mathrm{mol} \mathrm{cm}^{-2} \mathrm{~s}^{-1}\right)$ & $\theta$ & thickness \\
\hline$k_{L}$ & liquid-phase mass-transfer coefficient (m/s) & & \\
\hline LOI & loss on ignition (wt.\%) & Subscrip & \\
\hline$m$ & mass $(\mathrm{g})$ or $(\%)$ & $B$ & bulk \\
\hline$M$ & molar mass $(\mathrm{g} / \mathrm{mol})$ & $\mathrm{Br}$ & Brantley \\
\hline $\mathrm{Me} / \mathrm{Si}$ & metal (Mg and $\mathrm{Fe}$ ) silicon molar ratio & con & consumed \\
\hline$n$ & number of moles or reaction order (moles) or (-) & $e$ & effective \\
\hline$N$ & molar flux per unit of area $\left(\mathrm{mol} \mathrm{cm}-2 \mathrm{~s}^{-1}\right)$ & $L$ & liquid \\
\hline$r$ & reaction/dissolution rate $\left(\mathrm{mol} \mathrm{cm}^{-2} \mathrm{~s}^{-1}\right)$ & $\begin{array}{l}L \\
G\end{array}$ & geometric \\
\hline$R$ & gas constant $8.3144\left(\mathrm{~J} \mathrm{~mol}^{-1} \mathrm{~K}^{-1}\right)$ or radius $(\mu \mathrm{m})$ & $i$ & initial \\
\hline $\operatorname{Re}$ & Reynolds number, Eq. (13) & ol & olivine \\
\hline Sc & Schmidt number, Eq. (14) & $n$ & omvine \\
\hline Sh & Sherwood number, Eqs. (11) and (12) & $r$ & reaction \\
\hline SSA & specific surface area $\left(\mathrm{m}^{2} / \mathrm{g}\right)$ & so & solid \\
\hline$t$ & time $(\mathrm{h})$ & $t$ & time \\
\hline$T$ & temperature $(\mathrm{K})$ or $\left({ }^{\circ} \mathrm{C}\right)$ & $T$ & temperature \\
\hline$V$ & volume (L) & & \\
\hline$v_{s}$ & slip velocity $(\mathrm{m} / \mathrm{s})$ & & \\
\hline
\end{tabular}

and a solid content below $50 \mathrm{~g} / \mathrm{L}$ ) (Awad et al., 2000; Blum and Lasaga, 1988; Casey et al., 1993; Chen and Brantley, 2000; Daval et al., 2010, 2013; Grandstaff, 1986; Hänchen et al., 2006; Oelkers, 2001; Olsen and Donald Rimstidt, 2008; Pokrovsky and Schott, 2000b; Rosso and Rimstidt, 2000; Wogelius and Walther, 1992). These researchers agree that the dissolution mechanism is controlled by surface reactions, and the kinetics depends on the hydrogen ion activity, surface area of olivine and temperature:

$r=k_{T} \cdot a_{\mathrm{H}^{+}}^{n}=A \cdot \exp \left(\frac{-E_{a}}{R \cdot T}\right) \cdot a_{\mathrm{H}^{+}}^{n}$,

where $r$ is the dissolution rate $\left(\mathrm{mol} \mathrm{cm}^{-2} \mathrm{~s}^{-1}\right), k_{T}$ the rate constant $\left(\mathrm{mol} \mathrm{cm} \mathrm{c}^{-2} \mathrm{~s}^{-1}\right), A$ the pre-exponential factor $\left(\mathrm{mol} \mathrm{cm} \mathrm{cm}^{-2} \mathrm{~s}^{-1}\right), E_{a}$ the activation energy $(\mathrm{kJ} / \mathrm{mol}), R$ the gas constant $\left(8.314 \cdot 10^{-3}\right.$ $\left.\mathrm{kJ} \mathrm{mol}{ }^{-1} \mathrm{~K}^{-1}\right), T$ the temperature $(\mathrm{K}), a_{\mathrm{H}}^{+}$the hydrogen ion activity and $n$ the reaction order. In addition, in the last few years, the dissolution of olivine in carbonic acid in order to sequestrate $\mathrm{CO}_{2}$ has been extensively researched (Bearat et al., 2006; Declercq et al., 2013; Duro et al., 2005; Garcia et al., 2010; Giammar et al., 2005; Hänchen et al., 2006; Haug et al., 2010; Huijgen et al., 2005; King et al., 2010; Sissmann et al., 2014; Wang and Giammar, 2012).

A summary of the kinetic parameters together with the experimental conditions found in the literature can be seen in Table 1. The values of $E_{a}$ range from 25 to $105 \mathrm{~kJ} / \mathrm{mol}, n$ from 0.33 to 1.1 , and $r$ from $2 \cdot 10^{-13}$ to $5 \cdot 10^{-12} \mathrm{~mol} \mathrm{~cm}^{-2} \mathrm{~s}^{-1}$. However, the most frequently mentioned value for the reaction order is around 0.5 , and the activation energy is in the range between 43 and $80 \mathrm{~kJ} /$ $\mathrm{mol}$. There are several studies in which the dissolution parameters are out of these ranges. The study of Grandstaff (1986) is one of them, with values of $E_{a}$ of $38 \mathrm{~kJ} / \mathrm{mol}$ and $n$ of 1.1 . The different values established by this author could be the result of the high roughness factor of the studied dunite; this roughness factor is due to the presence of other minerals with higher specific surface area (SSA) than olivine. Van Herk et al. (1989) also reported anomalous activation energy values of $30 \mathrm{~kJ} / \mathrm{mol}$ together with high values of the roughness factor. Chen and Brantley (2000) reported a value of $E_{a}$ of $126 \mathrm{~kJ} / \mathrm{mol}$, which is surprisingly high, and an reaction order of 0.7 , which is also relatively high. He conducted experiments only at one temperature, obtaining the activation energy by combining his results with experiments from the literature (Blum and Lasaga, 1988; Wogelius and Walther, 1992). In addition, the roughness factor was 3 times smaller than the expected roughness factor for freshly crushed silicates (White, 1995). For these reasons his results can be considered to be unreliable. The remainder of the dissolution studies in Table 1 display similar values of $k_{T}$ and $n$.

Although the dissolution of olivine has been widely studied, only Jonckbloedt (1998) conducted experiments under conditions relevant for the production of nano-silica. These conditions included a negative $\mathrm{pH}$ to accelerate the reaction, a high solid content, an elevated conversion degree to increase the amount of nano-silica produced per batch and the use of available commercial dunites (i.e., not pristine olivine gemstones). Under these extreme conditions, the study of the olivine dissolution is still problematic for the following reasons: (1) the concentration of hydrogen ions is not constant because of the lack of $\mathrm{pH}$ sensors that could operate in such an aggressive environment; (2) the viscosity rises during the experiment (Lieftink and Geus, 1998); (3) the olivine surface area substantially decreases over time; (4) the quantity of silica released is much higher than the silica solubility.

Jonckbloedt studied the dissolution of olivine in $3 \mathrm{M}$ sulfuric acid with a stoichiometric amount of olivine and without keeping the pH level constant (Jonckbloedt, 1997). He also proposed a model for these conditions where the olivine particles shrink over time:

$\frac{d\left[\mathrm{H}^{+}\right]}{d t}(\mathrm{~mol} / \mathrm{min})=-\exp \left(\frac{-E_{a}}{R \cdot T}\right) \cdot 1.92 \cdot 10^{8} \cdot \mathrm{SSA}_{\mathrm{G}} \cdot a_{\mathrm{H}^{+}}^{0.33}$,

where $E_{a}$ is $66.5 \mathrm{~kJ} / \mathrm{mol}$ and $\mathrm{SSA}_{\mathrm{G}}$ (geometric specific surface area) is expressed in $\mathrm{m}^{2} / \mathrm{g}$. The particle shrinkage was incorporated into Jonckbloedt's model by means of the $\mathrm{SSA}_{\mathrm{G}}$, which changed over 
Table 1

Summary of the olivine dissolution kinetics in the literature.

\begin{tabular}{|c|c|c|c|c|c|c|c|c|c|}
\hline$A$ & $E_{a}$ & $k_{T}^{\mathrm{a}}$ & $n$ & $r^{a}$ & Solid content $(\mathrm{g} / \mathrm{L})$ & Frac. dis. (\%) & Acid & $\mathrm{pH}$ & Reference \\
\hline $1.53 \mathrm{E}-04$ & 38.1 & $3.2 \mathrm{E}-11$ & 1.10 & $2.0 \mathrm{E}-13$ & 2 & 6.6 & $\mathrm{HCl}$ & $3-5$ & Grandstaff (1986) \\
\hline $6.71 \mathrm{E}+02$ & 79.5 & $7.9 \mathrm{E}-12$ & 0.50 & $7.9 \mathrm{E}-13$ & $0.1-10$ & - & $\mathrm{HCl}$ & $2-10$ & Wogelius and Walther (1992) \\
\hline- & 25.0 & - & 0.33 & - & - & 80-99 & $\mathrm{HCl}$ & $1-3$ & Van Herk et al. (1989) \\
\hline- & 30.0 & - & 0.43 & - & - & 80-99 & $\mathrm{H}_{2} \mathrm{SO}_{4}$ & $1-3$ & Van Herk et al. (1989) \\
\hline- & 66.5 & - & 0.33 & - & 250 & 90-99 & $\mathrm{H}_{2} \mathrm{SO}_{4}$ & -0.7 to 1 & Jonckbloedt (1997) \\
\hline - & 71.5 & - & - & - & - & $10<$ & $\mathrm{H}_{2} \mathrm{SO}_{4}$ & $1-2$ & Awad et al. (2000) \\
\hline - & 125.6 & - & 0.70 & - & $0.5-3$ & 2 & $\mathrm{HCl}$ & $2-5$ & Chen and Brantley $(2000)^{\mathrm{b}}$ \\
\hline - & - & - & 0.50 & $2.0 \mathrm{E}-12$ & $4-16$ & $5<$ & $\mathrm{HCl}$ & $1-8$ & Pokrovsky and Schott (2000b) \\
\hline $3.46 \mathrm{E}-04$ & 42.6 & $1.2 \mathrm{E}-11$ & 0.50 & $1.2 \mathrm{E}-12$ & 30 & - & $\mathrm{HNO}_{3}$ & $2-4$ & Rosso and Rimstidt (2000) \\
\hline $1.90 \mathrm{E}-01$ & 63.8 & $1.3 \mathrm{E}-12$ & - & $1.3 \mathrm{E}-12$ & $3-8$ & - & $\mathrm{HCl}$ & 2 & Oelkers (2001) \\
\hline $8.54 \mathrm{E}-02$ & 52.9 & $4.6 \mathrm{E}-11$ & 0.46 & $5.5 \mathrm{E}-12$ & $0.5-10$ & $0.05-99$ & $\mathrm{HCl}, \mathrm{H}_{2} \mathrm{CO}_{3}$ & $2-12$ & Hänchen et al. (2006) \\
\hline- & - & $9.3 \mathrm{E}-12$ & 0.46 & $1.1 \mathrm{E}-12$ & 50 & - & $\mathrm{HNO}_{3}$ & $1-4$ & Olsen and Donald Rimstidt (2008) \\
\hline $1.13 \mathrm{E}+02$ & 70.5 & $5.0 \mathrm{E}-11$ & 0.46 & $6.0 \mathrm{E}-12$ & - & - & - & - & Rimstidt et al. $(2012)^{c}$ \\
\hline
\end{tabular}

$A, k_{T}$, are given in $\mathrm{mol} \mathrm{cm} \mathrm{c}^{-2} \mathrm{~s}^{-1}, E_{a}$ in $\mathrm{kJ} / \mathrm{mol}$ and $n$ in dimensionless units.

a Calculated at $\mathrm{pH}=2$ and $\mathrm{T}=25^{\circ} \mathrm{C}$.

b Experiments were done only at $65^{\circ} \mathrm{C}$ and $E_{a}$ was calculated by comparing these results with the literature.

c This study statistically obtained the kinetic parameters from 22 investigations.

time. Although Jonckbloedt's model was a considerable step forward in the elucidation of the kinetics of the dissolution of olivine under the conditions of olivine nano-silica production, there are several points on which more effort could have been attempted: (1) Jonckbloedt did not follow the standard equation (i.e., Eq. (2)) for the dissolution of olivine; (2) the specific surface area and the mineralogical composition of the olivine employed were not reported, so Jonckbloedt's results cannot be compared with other studies; (3) he obtained the kinetic parameters by fitting the plot of " $\log \left(\mathrm{d}\left[\mathrm{H}^{+}\right] / \mathrm{d} t\right)$ " versus " $-\mathrm{m} \log \left(\mathrm{mol}\left[\mathrm{H}^{+}\right]\right)-n \log \left(\right.$ act $\left.\left[\mathrm{H}^{+}\right]\right)$", which is a peculiar procedure. It would have been much simpler to obtain the kinetic parameters by fitting the data of the dissolution curve to Eq. (2); and (4) the reaction order is lower than in most of the dissolution studies. In addition to these points, the mass transport mechanism should be more deeply investigated because there are some controversial points in Jonckbloedt's work (Jonckbloedt, 1997): (1) the mass transfer through the liquid film was calculated considering a stagnant liquid and an effective diffusivity instead of the mass-transfer coefficient $\left(k_{L}\right)$ obtained from Sherwood's number; (2) the change in the viscosity of the slurry was not taken into account when calculating the mass transfer through the liquid film.

In this study, a kinetic model for the dissolution of olivine under the extreme conditions of the nano-silica production is developed. This work is structured in 3 parts: (1) chemical and mineralogical characterization of the dunites employed; (2) mechanism of the olivine dissolution focusing on the possible resistances to the transport; and (3) determination of the kinetic parameters $k_{T}$ and $n$. The results shown here demonstrate the mechanism dominating the process is the surface reaction, and that this kinetic model can be applied to predict the olivine dissolution under the nano-silica production conditions.

\section{Literature review on the olivine properties in dissolution studies}

Olivine refers to the mineral $(\mathrm{Mg}, \mathrm{Fe})_{2} \mathrm{SiO}_{4}$ and dunite refers to a rock where $90 \%$ or more of the volume is made up of olivine. The remaining $10 \%$ present in dunite ores can consist of pyroxenes, amphiboles, micas, carbonates, serpentines, etc.

In many dissolution studies, pure olivines were used (Awad et al., 2000; Chen and Brantley, 2000; Hänchen et al., 2006; Oelkers, 2001; Pokrovsky and Schott, 2000b). These olivines were handpicked; subsequently, they were thoroughly cleaned to remove any fine materials from the surface. However, for the production of olivine nano-silica, commercial dunite rocks - and sometimes even a by-product material with an olivine content lower than $90 \mathrm{wt} . \%$ - are employed because this process focuses on the industrial production of silica (Jonckbloedt, 1998; Lazaro et al., 2013a). The commercial dunites contain other components besides olivine. Therefore, the determination of the specific surface area associated with the olivine and the mineralogical composition of the dunite is required for the dissolution studies. The mineralogical characterization should focus on: (1) the content of minerals that consume a considerable amount of acid (besides olivine), such as carbonates; (2) the content of minerals that will not react with acid, or will react much slower than olivine; and (3) the olivine content.

Some properties of olivines, such as the forsterite/fayalite $\left(\mathrm{Mg}_{2} \mathrm{SiO}_{4} / \mathrm{Fe}_{2} \mathrm{SiO}_{4}\right)$ ratio, olivine content, specific surface area and roughness factor, used by different authors, are summarized in Table 2 . The roughness factor $(\lambda)$ of the olivines studied is in the range of 2-67 (see Table 2), while the roughness factor of freshly crushed silicates should be around 7 (White, 1995). There are four studies where a roughness factor above 20 was reported (Brantley and Mellott, 2000; Grandstaff, 1978; Haug et al., 2010; Van Herk et al., 1989). These high roughness factors are the result of a high $\mathrm{SSA}_{\mathrm{BET}}$ due to measurement errors or because the materials have a higher $\mathrm{SSA}_{\mathrm{BET}}$ than expected. The measurement errors can be attributed to either the gas used in the physisorption analysis or the magnitude of the surface area. Analyzing samples using nitrogen as an adsorbate results in values $40 \%$ higher than the values obtained using krypton (Brantley and Mellott, 2000). When the total surface area of the sample analyzed is smaller than $5 \mathrm{~m}^{2}$ and nitrogen is used, problems concerning the accuracy arise (Webb and Orr, 1997). On the other hand, the high SSA BET $_{\text {can be }}$ due to (1) the presence of porous materials, (2) fine particles or (3) bodies with cracks and etch pits. The SSA ${ }_{B E T}$ is highly affected by the presence of porosity, which can be due to the olivine itself or to the presence of other porous minerals. Most likely, the presence of other porous minerals leads to porosity because, as was stated by Brantley and Mellott (2000), olivine is usually not mesoporous or microporous (Brantley and Mellott, 2000). Thus, if $\lambda$ of the freshly crushed olivine is higher than 10 , a careful determination of the material should be carried out to demonstrate the absence of other minerals that could contribute more to the SSA than the olivine.

When commercial dunite rocks are used, a better alternative to determine the specific surface area is the Equation proposed by Brantley and Mellott (2000):

$\log \mathrm{SSA}_{\mathrm{Br}}=5.2-1.1 \cdot \log (d)$, 
Table 2

Summary of the literature data on the properties of olivine used in the dissolution studies.

\begin{tabular}{|c|c|c|c|c|c|c|c|c|c|}
\hline Reference & Olivine $^{\mathrm{a}}$ & $\mathrm{Fo}^{\mathrm{b}}(\%)$ & Hand $^{\mathrm{C}}$ & $\omega_{\mathrm{ol}}(\%)$ & $d(\mu \mathrm{m})$ & $d_{A}(\mu \mathrm{m})$ & Gas & $\mathrm{SSA}_{\mathrm{BET}}\left(\mathrm{cm}^{2} / \mathrm{g}\right)$ & $\lambda$ \\
\hline Grandstaff (1986) & HB & 81 & No & 95 & 74-194 & 134 & - & 9300 & 66.7 \\
\hline Van Herk et al. (1989) & DW & 93 & No & 99.9 & $105-125$ & 115 & $\mathrm{~N}_{2}$ & 6300 & 38.8 \\
\hline Wogelius and Walther (1992) & SCA & 91 & - & - & $250-420$ & 335 & $\mathrm{Kr}$ & 307 & 5.5 \\
\hline Jonckbloedt (1998) & NO & 93 & No & 92.6 & $63-300$ & 182 & $\mathrm{Kr}$ & - & - \\
\hline Awad et al. (2000) & SCA & 91 & Yes & 100 & $1 \mathrm{~mm}$ cubes & - & - & - & - \\
\hline Chen and Brantley (2000) & SCA & 91 & Yes & 100 & $75-150$ & 113 & $\mathrm{Kr}$ & 340 & 2.0 \\
\hline Pokrovsky and Schott (2000b) & SCA & 91 & Yes & 100 & $50-100$ & 75 & $\mathrm{Kr}$ & 800 & 3.2 \\
\hline Rosso and Rimstidt (2000) & GM & 92 & No & - & $250-350$ & 300 & $\mathrm{~N}_{2}$ & 405 & 6.5 \\
\hline Oelkers (2001) & SCA & 89 & Yes & 100 & $50-100$ & 75 & $\mathrm{Kr}$ & 800 & 3.2 \\
\hline Hänchen et al. (2006) & SCA & 91 & Yes & 100 & $90-180$ & 135 & $\mathrm{~N}_{2}$ & 797 & 5.8 \\
\hline Olsen and Donald Rimstidt (2008) & GM & 92 & No & - & $250-350$ & 150 & $\mathrm{Br}^{\mathrm{d}}$ & 528 & 4.2 \\
\hline Brantley and Mellott (2000) & SCA & - & - & - & $250-500$ & 375 & $\mathrm{Kr}$ & 329 & 6.6 \\
\hline Brantley and Mellott (2000) & TS & - & - & - & $250-500$ & 375 & $\mathrm{Kr}$ & 2340 & 46.9 \\
\hline Haug et al. $(2010)^{\mathrm{e}}$ & $\mathrm{NO}^{3}$ & 93 & No & 95 & $74-147$ & 111 & $\mathrm{~N}_{2}$ & 4700 & 27.8 \\
\hline
\end{tabular}

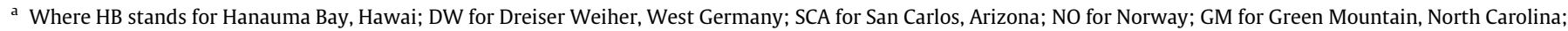
and TS for Twin Sisters Mountain, Washington.

${ }^{\mathrm{b}}$ Fo stands for forsterite content. $d$ refers to particle diameter and $d_{A}$ average particle diameter.

c Hand refers to handpicked.

d SSA was calculated using Brantley equation (Brantley and Mellott, 2000).

e This olivine was not used in the dissolution studies, but it originates from Norwegian mines like the dunites used in this study.

where $d$ is the grain size in $\mu \mathrm{m}$. This equation can be used to estimate either the SSA as a function of the grain size for impurity-free, laboratory-ground primary silicates without significant porosity or the external surface area of porous silicates.

The mineral composition of olivine (forsterite/fayalite ratio) is also a key factor of the dissolution of olivine, since fayalite is six times more reactive than forsterite (Wogelius and Walther, 1992). However, because the forsterite content of olivine is in the range 91-93\% (normally expressed as Fo92) in most studies, this factor has not been taken into account in the dissolution rate. In the case of Norwegian olivine, the dunite rocks have a forsterite content in the range of 92-93\% (Osland, 1997). The forsterite content can be estimated from the X-ray diffraction data (Yoder and Sahama, 1957) using:

Fo $(\%)=4233.91-1494.59 \cdot d_{130}$,

where $d_{130}$ is the spacing of the 130 peak in $\AA$. The Fo calculated from Eq. (5) is very sensitive to position shifts of the peak, having an error of $4 \%$.

\section{Materials and methods}

Two types of olivine dissolution experiments are presented: (1) a set of experiments (see Table 6) to establish the extent of the olivine dissolution and the olivine content; and (2) a set of experiments (see Table 13) to assess the kinetics of the dissolution of olivine. In addition, surface characterization experiments (see Figs. 5-7) after the dissolution of olivine were also conducted. The purpose of the surface characterization experiments was to study the surface of the olivine grains, focusing mainly on the presence or absence of a silica layer on the olivine grains after the reaction with acids.

Two commercially available Norwegian dunite rocks (dunites CRS and GL50) were used in this study. Both materials were analyzed by XRD, XRF, combustion infrared analysis, thermogravimetric analysis (TGA) and laser light scattering (LLS). Dunite GL50 was also characterized by scanning electron microscopy (SEM) in order to observe the texture and morphology of this material prior to dissolution and after dissolution with and without stirring. Two SEM devices were used: (1) a FEI XL-30 FEG-SEM equipped with a Schottky field emission gun operated at $20 \mathrm{keV}$ and with an EDAX $^{\circledR}$ energy-dispersive spectroscopy (EDS) device, and (2) a FEI Quanta 600 FEG-SEM with a Schottky field emitter gun (at voltage of $10 \mathrm{keV})$.
In order to determine the olivine content, the reactivity of both dunites was studied. This was performed at $90^{\circ} \mathrm{C}$ in acidic solutions with a molar ratio of hydrogen ions to olivine two times higher than that required by stoichiometry in order to establish the olivine content. The reagents used were $500 \mathrm{~mL}$ of $3 \mathrm{M}$ sulfuric acid and approximately $60 \mathrm{~g}$ of dunite. The particle sizes of the dunites investigated were in the range $300-500 \mu \mathrm{m}$ and $100-500 \mu \mathrm{m}$ for CRS-US and GL50, respectively. The initial molar ratio of hydrogen ions to olivine was doubled to complete the reaction within short times. The reagents were kept together in the reactor only long enough for all the olivine to be consumed and to minimize the reaction of the slow weathering silicates. The water evaporated during the reaction was around $9 \mathrm{~g}$ ( $1.5 \mathrm{~g}$ of water evaporated per hour) and was neglected, assuming a constant reaction volume. After the reaction, the residue was collected and weighed. This residue was cleaned 3 times with $500 \mathrm{~mL}$ of distilled water in order to remove any particles of colloidal silica. Subsequently, the residue was analyzed by XRD to check for the presence of olivine.

From these experiments, the olivine content $\left(\omega_{\mathrm{ol}}\right)$ in the dunites was calculated following:

$\omega_{\mathrm{ol}}(\%)=\frac{m_{\mathrm{ol}}}{m_{\mathrm{du}}}$,

$m_{\mathrm{ol}}=n_{\mathrm{ol}} \cdot M_{\mathrm{ol}}=\left[n_{\mathrm{H}^{+} \mathrm{con}}(\mathrm{mol})-2 n_{\mathrm{MgCO}_{3}}(\mathrm{~mol})\right] / 4 \cdot M_{\mathrm{ol}}$,

where $\omega_{\mathrm{ol}}$ is the mass fraction, $m_{\mathrm{ol}}$ the mass of olivine, $m_{\mathrm{du}}$ the mass of dunite, $n_{\mathrm{ol}}$ the number of moles of olivine, $M_{\mathrm{ol}}$ the molar mass of olivine, $n_{\mathrm{H}^{+}}$con the number of moles of hydrogen ions consumed and $n_{\mathrm{MgCO}_{3}}$ the number of moles of magnesite.z

Olivine dissolution experiments were carried out around 50, 70 and $90{ }^{\circ} \mathrm{C}$ with crushed dunite rocks of different fractions in vigorously stirred, thermostated reactors of 1 and $15 \mathrm{~L}$ to evaluate its dissolution kinetics. The temperature was kept constant by circulating water from a thermostat through a double wall. The reagents used were $500 \mathrm{~mL}$ (or $10 \mathrm{~L}$ for the $15 \mathrm{~L}$ reactor) of $3 \mathrm{M}$ sulfuric acid and the equivalent stoichiometric amount of olivine (previously dried). The concentration of hydrogen ions was determined by titration with a $0.05 \mathrm{M} \mathrm{Na}_{2} \mathrm{~B}_{4} \mathrm{O}_{7}$ solution at regular time intervals. The reaction was stopped when most of the olivine was consumed at pH around 1 (more details can be found in (Lazaro et al., 2012)).

The characterization of the olivine surface was performed by scanning electron microscope (SEM) using olivine GL50 with a particle size between 100 and $500 \mu \mathrm{m}$. A stoichiometric amount of this olivine reacted with $3 \mathrm{M}$ sulfuric acid at $90^{\circ} \mathrm{C}$ for $3 \mathrm{~h}$. Three 
olivine samples were analyzed: one before the dissolution, one after the dissolution in an unstirred reactor and the third one after the dissolution in a vigorously stirred reactor. The conditions of the olivine dissolution in a vigorously stirred reactor are similar to the conditions employed in the experiments conducted to assess the kinetics of the dissolution of olivine.

\section{Chemical and mineralogical characterization of the dunites}

The forsterite content, calculated with Eq. (5), was 93.1\%, 91.7\% and $93.8 \%$ for CRS, CRS-US and GL50, respectively, being in agreement with the range reported by Osland for Norwegian dunites (Osland, 1997). Hereafter, these dunites are considered to be rich in Fo93 olivine. Table 3 lists the commercial dunites used in this study and the theoretical composition of a Fo93 olivine with and without part of the iron replaced with nickel. This table shows that the $\mathrm{MgO}$ content for a pure olivine should be $51.6 \%$, and that there should not be any loss on ignition (LOI). However, the commercial dunites used in this study contain other minerals than olivine and some of these minerals should be rich in aluminum and chromium. The nickel content is related to the olivine mineral, resulting in a chemical composition of $\left(\mathrm{Mg}_{1.86} \mathrm{Fe}_{0.133} \mathrm{Ni}_{0.007}\right) \mathrm{SiO}_{4}$ for the olivine. GL50 and CRS-US have similar contents of MgO and exhibit a similar LOI, meaning similar contents of olivine.

The diffractograms of the samples CRS, CRS-US and GL50 are shown in Fig. 1, where quartz was added as reference material to correct the diffractogram displacement. Olivine is the main mineral in dunites CRS, CRS-US and GL50 although there are other minerals present as well (see Table 4). These minor minerals are amphiboles (actinolite and hornblende), micas (phlogopite), serpentine minerals (chrysotile), chlorite, talc, carbonates and enstatite. Most of these minerals have been identified in other Norwegian dunites (Haug et al., 2010; Kleiv and Thornhill, 2011) and are the reason that the content of $\mathrm{Al}_{2} \mathrm{O}_{3}$ is between $0.5 \%$ and $0.8 \%$ and the LOI is between $0.7 \%$ and $1.3 \%$. Magnesite was only found in the diffractogram of CRS; however, the combustion infrared analysis detected a small amount of carbonates (between $0.2 \%$ and $0.4 \%$ ) in all the samples (see Table 5).

The other silicate minerals present in the dunites which are not olivine, react with acid much more slowly than olivine. Olivine reacts approximately 50 times (at pH values of 2 and $25^{\circ} \mathrm{C}$ ) more rapidly than enstatite (Ferruzzi, 1993; Olsen and Donald

Table 3

Chemical composition of commercial dunites CRS, CRS-US and GL50 and of olivine Fo93 with and without replacement of nickel for iron.

\begin{tabular}{|c|c|c|c|c|c|c|c|c|c|c|c|c|c|}
\hline Name & $d(\mu \mathrm{m})$ & $\mathrm{MgO}$ & $\mathrm{Fe}_{2} \mathrm{O}_{3}$ & $\mathrm{SiO}_{2}$ & $\mathrm{Cr}_{2} \mathrm{O}_{3}$ & $\mathrm{Al}_{2} \mathrm{O}_{3}$ & $\mathrm{NiO}$ & $\mathrm{MnO}$ & $\mathrm{CaO}$ & $\mathrm{Na}_{2} \mathrm{O}$ & $\mathrm{K}_{2} \mathrm{O}$ & LOI & Other oxides \\
\hline CRS & $63-2000$ & 47.41 & 7.84 & 41.42 & 0.31 & 0.75 & 0.33 & 0.12 & 0.34 & 0.06 & 0.01 & 1.29 & 0.12 \\
\hline CRS-US & $63-2000$ & 47.59 & 8.28 & 40.96 & 0.33 & 0.64 & 0.35 & 0.11 & 0.29 & 0.04 & 0.07 & 1.19 & 0.15 \\
\hline CRS-US & $300-500$ & 48.46 & 7.90 & 40.67 & 0.25 & 0.65 & 0.36 & 0.10 & 0.2 & 0.02 & 0.05 & 0.89 & 0.45 \\
\hline GL50 & $100-500$ & 48.78 & 7.40 & 40.91 & 0.26 & 0.52 & 0.35 & 0.10 & 0.09 & 0.02 & 0.04 & 0.73 & 0.80 \\
\hline Olivine (Fo93) ${ }^{1}$ & - & 51.65 & 6.94 & 41.41 & - & - & - & - & - & - & - & - & - \\
\hline Olivine (Fo93) ${ }^{2}$ & - & 51.64 & 6.59 & 41.41 & - & - & 0.36 & - & - & - & - & - & - \\
\hline
\end{tabular}

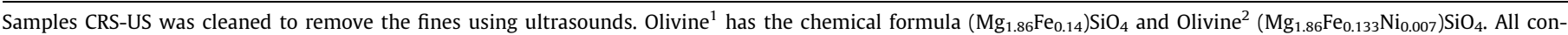
centrations are expressed in wt.\%.

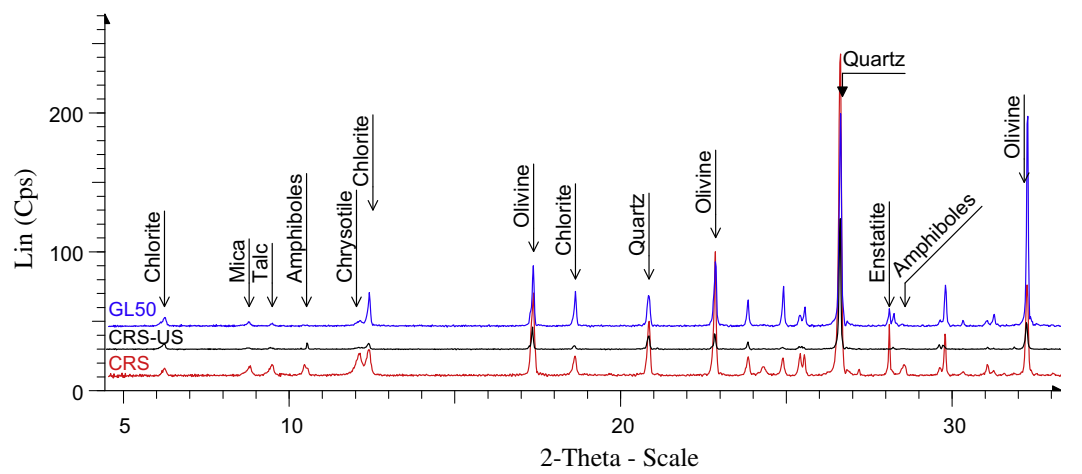

Fig. 1. Diffractograms of dunites CRS, CRS-US and GL50 prior to dissolution. Quartz was added as reference material.

Table 4

Mineralogical patterns found in the diffractogram of dunites CRS, CRS-US and GL50 before and after dissolution in acid.

\begin{tabular}{|c|c|c|c|c|c|c|}
\hline Compound name & PDF number & CRS & CRS-US & GL50 & RE-CRS-US & RE-GL50 \\
\hline Olivine & 01-079-1192 & $\mathrm{Y}$ & $\mathrm{Y}$ & $\mathrm{Y}$ & $\mathrm{N}$ & $\mathrm{N}$ \\
\hline Actinolite & $00-041-1366$ & $\mathrm{Y}$ & $\mathrm{Y}$ & $\mathrm{N}$ & $\mathrm{Y}$ & $\mathrm{Y}$ \\
\hline Hornblende & $01-071-1062$ & $\mathrm{Y}$ & $\mathrm{Y}$ & $\mathrm{N}$ & $\mathrm{Y}$ & $\mathrm{Y}$ \\
\hline Biotite & 01-088-1899 & $\mathrm{Y}$ & $\mathrm{Y}$ & $\mathrm{Y}$ & $\mathrm{N}$ & $\mathrm{N}$ \\
\hline Phlogopite & $01-085-2275$ & $\mathrm{Y}$ & $\mathrm{Y}$ & $\mathrm{Y}$ & $\mathrm{N}$ & $\mathrm{N}$ \\
\hline Chrysotile & $00-025-0645$ & $\mathrm{Y}$ & $\mathrm{Y}$ & $\mathrm{Y}$ & $\mathrm{N}$ & $\mathrm{N}$ \\
\hline Chlorite, chromian & 01-083-1381 & $\mathrm{Y}$ & $\mathrm{Y}$ & $\mathrm{Y}$ & $\mathrm{Y}$ & $\mathrm{Y}$ \\
\hline Talc & 01-073-0147 & $\mathrm{Y}$ & $\mathrm{Y}$ & $\mathrm{Y}$ & $\mathrm{Y}$ & $\mathrm{Y}$ \\
\hline Magnesite & $01-080-0101$ & $\mathrm{Y}$ & $\mathrm{N}$ & $\mathrm{N}$ & $\mathrm{N}$ & $\mathrm{N}$ \\
\hline Enstatite ferroan & 01-088-1911 & $\mathrm{Y}$ & $\mathrm{N}$ & $\mathrm{Y}$ & $\mathrm{Y}$ & $\mathrm{Y}$ \\
\hline
\end{tabular}

PDF number refers to the powder diffraction file number from the PDF-2 Database, Y present and $\mathrm{N}$ absent. 
Table 5

Carbon content, magnesite content and magnesite LOI of dunites CRS, CRS-US and GL50.

\begin{tabular}{llll}
\hline Name & C-total (\%) & Magnesite $^{\mathrm{a}}(\%)$ & LOI $^{\mathrm{b}}(\%)$ \\
\hline CRS & 0.05 & 0.35 & 0.18 \\
CRS-US & 0.06 & 0.42 & 0.22 \\
GL50 & 0.03 & 0.21 & 0.11 \\
\hline
\end{tabular}

a Magnesite content calculated considering that all the carbon is present in this mineralogical form.

$\mathrm{b}$ LOI related to the magnesite decomposition.

Rimstidt, 2008), which is the second fastest weathering silicate present. Thus, for short reaction times, the other silicates may be considered as inert materials regarding the consumption of hydrogen ions. Furthermore, the content of these other minerals is very small. Consequently, the hydrogen ion consumption will only be related to the content of olivine and carbonates.

Table 6 lists the experimental conditions of the reactivity experiments of dunites GL50 and CRS-US, the moles of hydrogen ion consumed and the olivine content determined using Eqs. (6) and (7). After a reaction time long enough (around $6 \mathrm{~h}$ for these experiments) the magnesite and olivine, which are the most reactive minerals, were completely consumed. The residual material was collected and analyzed by XRD. The diffractograms of these residue materials exhibited actinolite (amphiboles), chlorite, talc and enstatite for residue RE-CRS-US and RE-GL50 (see Table 4), but not olivine, which indicates that the olivine was completely consumed.

The average olivine content determined from the reactivity experiments (see Table 6) is 88.9 and $88.4 \mathrm{wt} . \%$ for GL50 and CRS-US, respectively. Therefore, around $11 \mathrm{wt} . \%$ of the material of these dunite rocks consists of different minerals than olivine.

\section{Mechanism of the olivine dissolution}

Prior to investigating the reaction kinetics of the dissolution of olivine under our experimental conditions, the mechanism of the overall process should be studied. At the experimental conditions employed for the dissolution of olivine for nano-silica production (solid content of $250 \mathrm{~g} / \mathrm{L}$ and fraction dissolved above 90\%), the study of the process mechanism is fundamental. The mechanism controlling the dissolution of olivine in acid depends on the mixing device, reaction kinetics, silica concentration, silica solubility, silica polymerization and fluid properties.

The most common reaction models in leaching and dissolution of solids are shown in Fig. 2. Model (a) illustrates a spherical particle that shrinks over time without any layer covering the surface. Model (b) shows a spherical particle in which the core shrinks over time, but the solid layer covering the surface of the cores increases over time; therefore, the size of the particle (core plus solid layer) remains constant. Model (c) describes a spherical particle where the core shrinks over time together with a solid layer of constant thickness. More details about these models can be found in Levenspiel (1999), Liddell (2005) and Safari et al. (2009).

When a solid layer covers the grains of olivine there are 3 possible resistances to the transport of ions from the bulk liquid to the

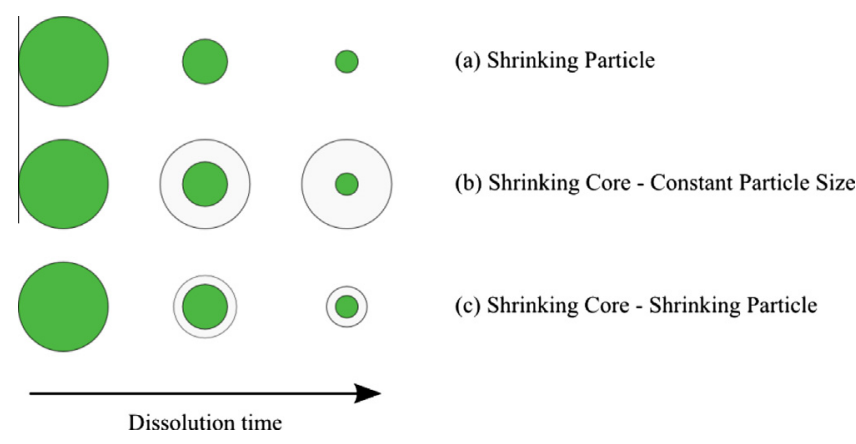

Fig. 2. Dissolution models of solid particles (Safari et al., 2009).

olivine surface and vice versa: (1) diffusion through the liquid film, (2) diffusion through a solid layer and (3) reaction on the surface. When all the resistances influence the dissolution of olivine, the shrinking of the core spherical particles can be described in analogy with Levenspiel (1999):

$$
\frac{d\left(R_{\mathrm{ol}}\right)}{d t}=-\frac{\left[\mathrm{H}^{+}\right] /\left(4 \cdot \rho_{\mathrm{ol}}\right)}{\frac{R_{\mathrm{ol}}^{2}}{R_{\mathrm{ol}+\theta}^{2} \cdot k_{L}}+\frac{\theta_{\mathrm{Si}} \cdot R_{\mathrm{ol}}}{R_{\mathrm{ol}+\theta} \cdot D_{e}}+\frac{1}{k_{T}}},
$$

where $R_{\mathrm{ol}}$ is the core radius of olivine grains, $R_{\mathrm{ol}+\theta}$ the radius of the olivine grain covered by a solid layer, $\theta$ the thickness of the solid layer, $k_{L}$ the mass-transfer coefficient in the liquid film, $D_{e}$ the effective diffusion coefficient through the solid layer, $k_{T}$ the reaction rate constant of the olivine dissolution and $\rho_{\mathrm{ol}}$ the olivine density. In steady state, the molar flux in each step should be equal to the others:

$N=r=N_{L}=N_{\mathrm{so}}$,

where $N$ is the overall flux rate for the dissolution of olivine, $r$ is the reaction rate, $N_{L}$ is the molar flux through the liquid layer and $N_{\text {so }}$ is the molar flux through the solid layer, all of them in $\mathrm{mol} \mathrm{s}^{-1} \mathrm{~cm}^{-2}$.

\subsection{Diffusion through the liquid film as the limiting step}

When the diffusion through the liquid film controls the process, the hydrogen ion concentration around the particle can be described by Fig. 3 and Eq. (10).

$N_{L, H}=k_{L} \cdot\left(\left[\mathrm{H}^{+}\right]_{B}-\left[\mathrm{H}^{+}\right]_{\mathrm{ol}}\right) \approx k_{L} \cdot\left[\mathrm{H}^{+}\right]_{B}$,

where $\left[\mathrm{H}^{+}\right]_{B}$ is the concentration of hydrogen ions in the bulk liquid and $\left[\mathrm{H}^{+}\right]_{\mathrm{ol}}$ the concentration of hydrogen ions on the surface of olivine. In the case that the diffusion through the liquid film controls the process, the surface reaction resistance, and, therefore, $\left[\mathrm{H}^{+}\right]_{\mathrm{ol}}$, can be neglected. The Sherwood's number (Sh) for diffusion from a sphere into a stagnant medium is described by:

$\mathrm{Sh}=\frac{k_{L} \cdot d}{D}=2$,

where $k_{L}$ is the mass-transfer coefficient, $d$ the particle diameter and $D$ the diffusion coefficient.

For forced convection, the important hydrodynamic variables are the relative velocity between the solid and the liquid, also

Table 6

Experimental conditions of the reactivity experiments of dunites CRS-US and GL50, the moles of hydrogen ion consumed and the olivine content.

\begin{tabular}{|c|c|c|c|c|c|c|c|c|c|}
\hline Name & $V_{\mathrm{H}_{2} \mathrm{SO}_{4}}(\mathrm{~mL})$ & {$\left[\mathrm{H}^{+}\right](\mathrm{mol} / \mathrm{L})$} & Dunite & $m_{\mathrm{du}}(\mathrm{g})$ & $T_{r}\left({ }^{\circ} \mathrm{C}\right)$ & $R_{\mathrm{H} / \mathrm{ol}}$ & $n_{\mathrm{H}}^{+}(\mathrm{mol})$ & $n_{\mathrm{ol}}(\mathrm{mol})$ & $\omega_{\mathrm{ol}}(\%)$ \\
\hline RE-1 & 501.9 & 6.05 & GL50 & 62.25 & 90.1 & 7.9 & 1.523 & 0.381 & 88.8 \\
\hline RE-2 & 502.4 & 6.05 & GL50 & 62.21 & 90.0 & 7.9 & 1.524 & 0.381 & 88.9 \\
\hline RE-3 & 501.6 & 6.08 & CRS-US & 62.29 & 90.3 & 8.0 & 1.529 & 0.382 & 89.1 \\
\hline RE-4 & 500.7 & 6.07 & CRS-US & 62.69 & 90.1 & 7.9 & 1.514 & 0.378 & 87.6 \\
\hline
\end{tabular}




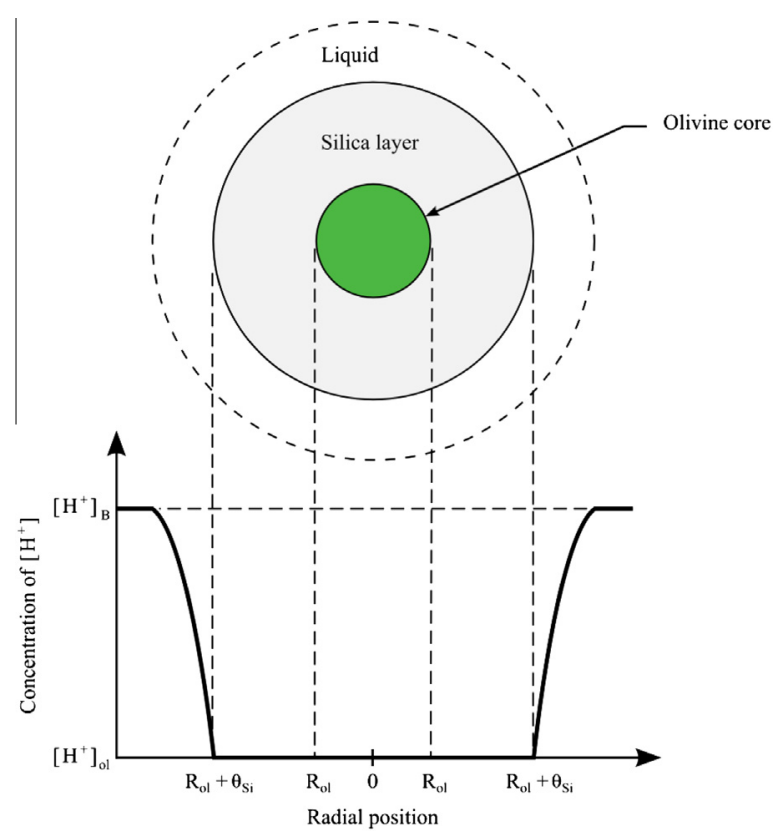

Fig. 3. Diagram of a reacting olivine particle when the diffusion through the liquid film is the rate limiting step (Levenspiel, 1999).

known as slip velocity $\left(v_{s}\right)$, and the rate of renewal of the liquid layer around the solid particle (Paul et al., 2004). The mass-transfer coefficient can be estimated following the procedure explained in Paul et al. (2004). This coefficient is calculated using an empirical equation for solid particles suspended in an agitated vessel when a significant density difference exists (Levins and Glastonbury, $1972)$. In this procedure, the free settling velocity $\left(v_{t}\right)$ - which refers to the decantation speed of a solid particle in a stagnant fluid - is used instead of the slip velocity.

$\mathrm{Sh}=\frac{k_{L} \cdot d}{D}=2+0.44 \cdot \mathrm{Re}^{1 / 2} \cdot \mathrm{Sc}^{0.38}$,

$\operatorname{Re}=\frac{\rho_{L} \cdot v_{s} \cdot d}{\mu}$,

Sc $=\frac{\mu}{\rho_{L} \cdot D}$,

where Re is the Reynolds number, Sc the Schmidt number, $\mu$ the viscosity and $\rho_{L}$ the density of the liquid. Eq. (12) is valid for solid-liquid systems where the particles settle faster than of $5 \cdot 10^{-4} \mathrm{~m} / \mathrm{s}$. The free settling velocity can be calculated following (Paul et al., 2004):

$v_{t}=\left(\frac{4 \cdot g \cdot\left(\rho_{\mathrm{ol}}-\rho_{L}\right)}{3 \cdot C_{D} \cdot \rho_{L}}\right)^{1 / 2}$,

where $g$ is the gravitational constant and $C_{D}$ the drag coefficient. $C_{D}$, is a function of the Reynolds number and particle shape (Paul et al., 2004).

Table 7 lists the density and viscosity at $20^{\circ} \mathrm{C}$ of the slurry during the dissolution of olivine in acid under the following conditions: $3 \mathrm{M} \mathrm{H}_{2} \mathrm{SO}_{4}$, a solid content of $250 \mathrm{~g} / \mathrm{L}$ and at $70^{\circ} \mathrm{C}$. The viscosity was measured with a Haake Rotovisco RV 20 at a shear rate of $64 \mathrm{~s}^{-1}$, which is similar to the average shear rate (calculated following the procedure in (Paul et al., 2004)) in the reactor. The flux of hydrogen ions through the fluid film for different conditions, using the initial concentration of hydrogen ion in the calculations, is listed in Table 8. The diffusion coefficients used in these calculations are in the range $10^{-8}$ to $10^{-10} \mathrm{~m}^{2} / \mathrm{s}$, which are typical values for liquids (Perry and Green, 2008). For some of the calculations in Table 8 , the free settling velocity is smaller than $5 \cdot 10^{-4} \mathrm{~m} / \mathrm{s}$; therefore, Eq. (12) is not valid. This equation can be used when the olivine particle size is bigger than 28, 126 and $150 \mu \mathrm{m}$ for the conditions in Table 8, respectively. When the velocity is lower than $5 \cdot 10^{-4} \mathrm{~m} / \mathrm{s}$, the Sherwood number is close to two, which is the value for spheres in a stagnant fluid, and this equation is still used as an (under)estimation. In the real case, the slurry is vigorously agitated and the mass-transfer coefficient will be always higher than the values obtained using the method with the free settling velocity. The slowest mass-transfer rate calculated through the liquid film at the beginning and at the end of the dissolution (see Table 8) is $1 \cdot 10^{-5}$ and $2 \cdot 10^{-6} \mathrm{~mol} \mathrm{~s}^{-1} \mathrm{~cm}^{-2}$, respectively.

\subsection{The diffusion through a solid layer as the limiting step}

When the diffusion through a solid layer controls the process, the hydrogen ion concentration around the particle is illustrated by Fig. 4 and described by:

$N_{\mathrm{so}, \mathrm{H}}=D_{e} \frac{\left[\mathrm{H}^{+}\right]_{B}-\left[\mathrm{H}^{+}\right]_{\mathrm{ol}}}{\theta} \approx D_{e} \frac{\left[\mathrm{H}^{+}\right]_{B}}{\theta}$,

where $D_{e}$ is the effective diffusion coefficient and $\theta$ the thickness of the solid layer. In the case that the diffusion through the solid layer controls the process, the surface reaction resistance and $\left[\mathrm{H}^{+}\right]_{\mathrm{ol}}$ can be neglected. Daval et al. (2011) studied the formation of a silica layer around the olivine grains in small unstirred capsules finding a $40 \mathrm{~nm}$ layer around the olivine grains with a $D_{e}$ of $3 \cdot 10^{-22} \mathrm{~m}^{2} / \mathrm{s}$. Safari et al. (2009) developed a mathematical model for the leaching of zinc ores containing silicates where a silica layer covering the ores was taken into account. The values obtained from Safari's model are a $D_{e}$ that depends on the temperature for the diffusion through a silica layer of $1.2 \mu \mathrm{m}$ :

$\ln D_{e}=-12.92-\frac{28167.83}{R \cdot T}$,

where $R$ is $8.314 \mathrm{~J} \mathrm{~mol}^{-1} \mathrm{~K}^{-1}$. At $90{ }^{\circ} \mathrm{C}$, the $D_{e}$ is $2.2 \cdot 10^{-10} \mathrm{~m}^{2} / \mathrm{s}$. In Perry's Handbook (Perry and Green, 2008) the diffusion coefficient through solids given is in the range of $10^{-10}$ and $10^{-34} \mathrm{~m}^{2} / \mathrm{s}$ and the reference value proposed is $10^{-14} \mathrm{~m}^{2} / \mathrm{s}$.

Table 9 lists the flux of hydrogen ions through a solid layer for the three different diffusion coefficients (Daval et al., 2011; Perry and Green, 2008; Safari et al., 2009). There is a significant difference between the fluxes in this table because the Daval diffusion coefficient is $10^{12}$ times lower than the Safari diffusivity. This difference in the diffusion coefficient of the silica layer can be due to the different surrounding medium of the solution, as was pointed out by Sissmann et al. (2013). Sissmann found a nanometric solid layer around the olivine grains, and he proposed that this layer was only hindering the dissolution when the oxidized $\mathrm{Fe}^{3+}$ was present together with the silica layer. The passivating phenomenon can be interpreted as the presence of a surface layer with a higher molar density than the underlying material (Putnis, 2009). Thus, if the iron does not precipitate, the solid layer is made up only of silica, and, therefore, the solid layer is less dense.

Table 7

Density and viscosity of the slurry during the olivine dissolution at $20^{\circ} \mathrm{C}$.

\begin{tabular}{lll}
\hline Time & $\rho_{\mathrm{SI}}\left(\mathrm{kg} / \mathrm{m}^{3}\right)$ & $\mu_{\mathrm{Sl}}(\mathrm{Pa} \mathrm{s})$ \\
\hline At the beginning of reaction & 1180 & 0.0017 \\
$5<X<50$ & 1276 & 0.0332 \\
End of reaction & 1364 & 0.0452 \\
\hline
\end{tabular}

At the beginning of the reaction, the $\rho$ and $\mu$ of the slurry refer to the density and viscosity of $3 \mathrm{M} \mathrm{H}_{2} \mathrm{SO}_{4}$ found in Lide (2009). $X$ refers to the conversion in \%. The viscosity was measured at a shear rate of $64 \mathrm{~s}^{-1}$. 
Table 8

Mass-transfer of hydrogen ions at the initial conditions, between $5 \%$ and $50 \%$ conversion, and at the end of the reaction.

\begin{tabular}{|c|c|c|c|c|c|c|c|c|c|}
\hline$\rho_{\mathrm{SI}}\left(\mathrm{kg} / \mathrm{m}^{3}\right)$ & $\mu_{\mathrm{SI}}(\mathrm{Pa} \mathrm{s})$ & $D\left(\mathrm{~m}^{2} / \mathrm{s}\right)$ & $d(\mu \mathrm{m})$ & $v_{t}(\mathrm{~m} / \mathrm{s})$ & $\mathrm{Re}$ & $\mathrm{Sc}$ & Sh & $k_{L}(\mathrm{~m} / \mathrm{s})$ & $N_{L, H}\left(\mathrm{~mol} \mathrm{~s}^{-1} \mathrm{~cm}^{-2}\right)$ \\
\hline 1180 & 0.0017 & $1.00 \mathrm{E}-09$ & 10 & $6.51 \mathrm{E}-05$ & $4.52 \mathrm{E}-04$ & $1.44 \mathrm{E}+03$ & 2.15 & $2.15 \mathrm{E}-04$ & $1.29 \mathrm{E}-04$ \\
\hline 1180 & 0.0017 & $1.00 \mathrm{E}-09$ & 50 & $1.63 \mathrm{E}-03$ & $5.65 \mathrm{E}-02$ & $1.44 \mathrm{E}+03$ & 3.66 & $7.32 \mathrm{E}-05$ & $4.39 \mathrm{E}-05$ \\
\hline 1180 & 0.0017 & $1.00 \mathrm{E}-09$ & 100 & $1.23 \mathrm{E}-02$ & $8.54 \mathrm{E}-01$ & $1.44 \mathrm{E}+03$ & 8.45 & $8.45 \mathrm{E}-05$ & $5.07 \mathrm{E}-05$ \\
\hline 1180 & 0.0017 & $1.00 \mathrm{E}-09$ & 500 & $7.74 \mathrm{E}-02$ & $2.69 \mathrm{E}+01$ & $1.44 \mathrm{E}+03$ & 38.17 & $7.63 \mathrm{E}-05$ & $4.58 \mathrm{E}-05$ \\
\hline 1180 & 0.0017 & $1.00 \mathrm{E}-08$ & 100 & $1.23 \mathrm{E}-02$ & $8.54 \mathrm{E}-01$ & $1.44 \mathrm{E}+02$ & 4.69 & $4.69 \mathrm{E}-04$ & $2.81 \mathrm{E}-04$ \\
\hline 1180 & 0.0017 & $1.00 \mathrm{E}-09$ & 100 & $1.23 \mathrm{E}-02$ & $8.54 \mathrm{E}-01$ & $1.44 \mathrm{E}+03$ & 8.45 & $8.45 \mathrm{E}-05$ & $5.07 \mathrm{E}-05$ \\
\hline 1180 & 0.0017 & $1.00 \mathrm{E}-10$ & 100 & $1.23 \mathrm{E}-02$ & $8.54 \mathrm{E}-01$ & $1.44 \mathrm{E}+04$ & 17.47 & $1.75 \mathrm{E}-05$ & $1.05 \mathrm{E}-05$ \\
\hline 1276 & 0.0332 & $1.00 \mathrm{E}-09$ & 10 & $3.18 \mathrm{E}-06$ & $1.22 \mathrm{E}-06$ & $2.60 \mathrm{E}+04$ & 2.02 & $2.02 \mathrm{E}-04$ & $1.21 \mathrm{E}-04$ \\
\hline 1276 & 0.0332 & $1.00 \mathrm{E}-09$ & 100 & $3.18 \mathrm{E}-04$ & $1.22 \mathrm{E}-03$ & $2.60 \mathrm{E}+04$ & 2.73 & $2.73 \mathrm{E}-05$ & $1.64 \mathrm{E}-05$ \\
\hline 1276 & 0.0332 & $1.00 \mathrm{E}-09$ & 500 & $7.95 \mathrm{E}-03$ & $1.53 \mathrm{E}-01$ & $2.60 \mathrm{E}+04$ & 10.19 & $2.04 \mathrm{E}-05$ & $1.22 \mathrm{E}-05$ \\
\hline 1276 & 0.0332 & $1.00 \mathrm{E}-08$ & 100 & $3.18 \mathrm{E}-04$ & $1.22 \mathrm{E}-03$ & $2.60 \mathrm{E}+03$ & 2.31 & $2.31 \mathrm{E}-04$ & $1.38 \mathrm{E}-04$ \\
\hline 1276 & 0.0332 & $1.00 \mathrm{E}-09$ & 100 & $3.18 \mathrm{E}-04$ & $1.22 \mathrm{E}-03$ & $2.60 \mathrm{E}+04$ & 2.73 & $2.73 \mathrm{E}-05$ & $1.64 \mathrm{E}-05$ \\
\hline 1276 & 0.0332 & $1.00 \mathrm{E}-10$ & 100 & $3.18 \mathrm{E}-04$ & $1.22 \mathrm{E}-03$ & $2.60 \mathrm{E}+05$ & 3.76 & $3.76 \mathrm{E}-06$ & $2.25 \mathrm{E}-06$ \\
\hline 1364 & 0.0452 & $1.00 \mathrm{E}-09$ & 10 & $2.22 \mathrm{E}-06$ & $6.71 \mathrm{E}-07$ & $3.32 \mathrm{E}+04$ & 2.02 & $2.02 \mathrm{E}-04$ & $1.21 \mathrm{E}-04$ \\
\hline 1364 & 0.0452 & $1.00 \mathrm{E}-09$ & 100 & $2.22 \mathrm{E}-04$ & $6.71 \mathrm{E}-04$ & $3.32 \mathrm{E}+04$ & 2.60 & $2.60 \mathrm{E}-05$ & $1.56 \mathrm{E}-05$ \\
\hline 1364 & 0.0452 & $1.00 \mathrm{E}-09$ & 500 & $5.56 \mathrm{E}-03$ & $8.39 \mathrm{E}-02$ & $3.32 \mathrm{E}+04$ & 8.65 & $1.73 \mathrm{E}-05$ & $1.04 \mathrm{E}-05$ \\
\hline 1364 & 0.0452 & $1.00 \mathrm{E}-08$ & 100 & $2.22 \mathrm{E}-04$ & $6.71 \mathrm{E}-04$ & $3.32 \mathrm{E}+03$ & 2.25 & $2.25 \mathrm{E}-04$ & $1.35 \mathrm{E}-04$ \\
\hline 1364 & 0.0452 & $1.00 \mathrm{E}-09$ & 100 & $2.22 \mathrm{E}-04$ & $6.71 \mathrm{E}-04$ & $3.32 \mathrm{E}+04$ & 2.60 & $2.60 \mathrm{E}-05$ & $1.56 \mathrm{E}-05$ \\
\hline 1364 & 0.0452 & $1.00 \mathrm{E}-10$ & 100 & $2.22 \mathrm{E}-04$ & $6.71 \mathrm{E}-04$ & $3.32 \mathrm{E}+05$ & 3.43 & $3.43 \mathrm{E}-06$ & $2.06 \mathrm{E}-06$ \\
\hline
\end{tabular}

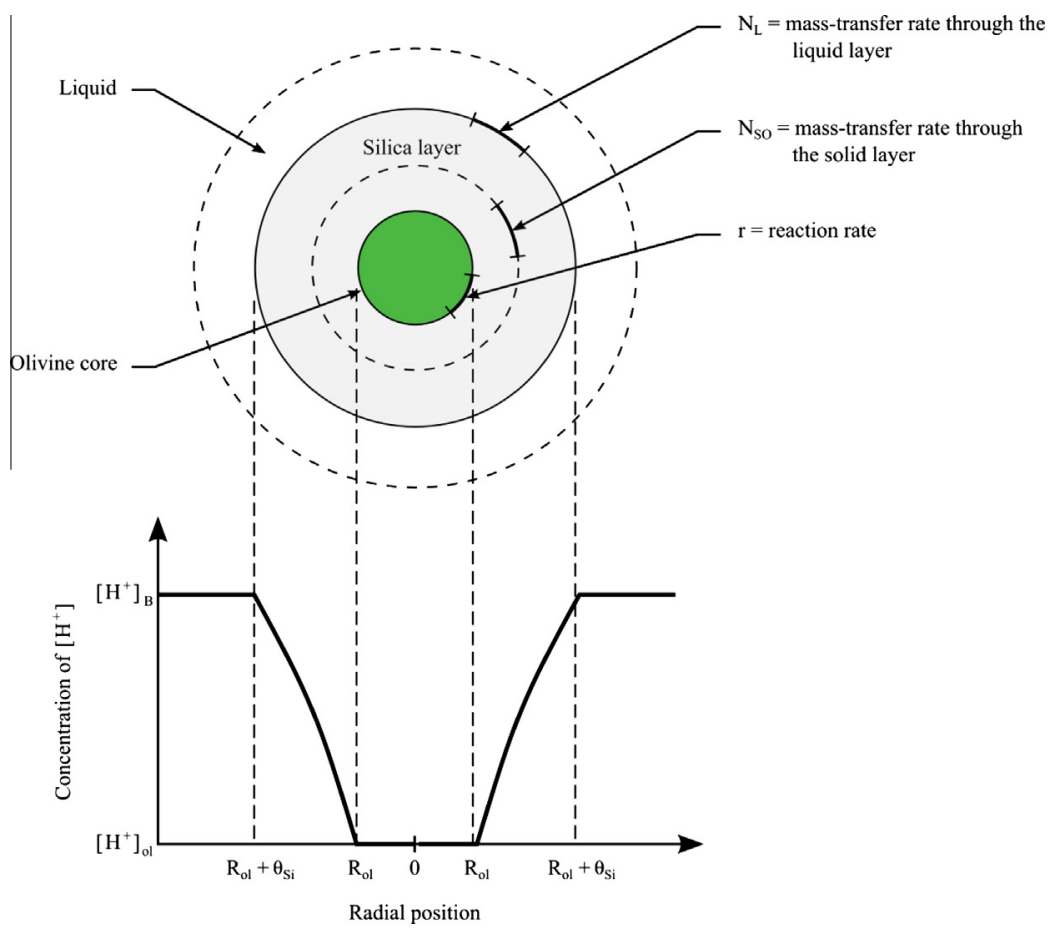

Fig. 4. Diagram of a reacting olivine particle when the diffusion through the solid layer is the limiting step (Levenspiel, 1999).

Table 9

Hydrogen ion flux through a solid layer.

\begin{tabular}{|c|c|c|c|}
\hline $\begin{array}{l}D_{e}\left(\mathrm{~m}^{2} / \mathrm{s}\right) \\
\text { Reference } \\
\theta(\mathrm{nm})\end{array}$ & $\begin{array}{l}\text { 3.00E-22 } \\
\text { Daval (Daval et al., 2011) } \\
N_{\text {so }}\left(\mathrm{mol} \mathrm{s}^{-1} \mathrm{~cm}^{-2}\right)\end{array}$ & $\begin{array}{l}2.17 \mathrm{E}-10 \\
\text { Safari (Safari et al., 2009) } \\
N_{\text {so }}\left(\mathrm{mol} \mathrm{s}^{-1} \mathrm{~cm}^{-2}\right)\end{array}$ & $\begin{array}{l}1.00 \mathrm{E}-14 \\
\text { Perry HB (Perry and Green, 2008) } \\
N_{\text {so }}\left(\mathrm{mol} \mathrm{s}^{-1} \mathrm{~cm}^{-2}\right)\end{array}$ \\
\hline 1 & $1.80 \mathrm{E}-13$ & $1.30 \mathrm{E}-01$ & $6.00 \mathrm{E}-06$ \\
\hline 10 & $1.80 \mathrm{E}-14$ & $1.30 \mathrm{E}-02$ & $6.00 \mathrm{E}-07$ \\
\hline 50 & $3.60 \mathrm{E}-15$ & $2.61 \mathrm{E}-03$ & $1.20 \mathrm{E}-07$ \\
\hline 500 & $3.60 \mathrm{E}-16$ & $2.61 \mathrm{E}-04$ & $1.20 \mathrm{E}-09$ \\
\hline
\end{tabular}


Table 10

Time to release 2.5 and $135 \mathrm{mmol} / \mathrm{L}$ by the dissolution of olivine.

\begin{tabular}{llll}
\hline Sample & $T_{r}\left({ }^{\circ} \mathrm{C}\right)$ & $t_{1}(\mathrm{~s})$ & $t_{2}(\mathrm{~min})$ \\
\hline NS-2 & 52.0 & 90 & 55 \\
NS-10 & 89.8 & 4 & 3.4
\end{tabular}

Where $t_{1}$ and $t_{2}$ are the required time to produce 2.5 and $135 \mathrm{mmol} / \mathrm{L}$ of silica.

\subsubsection{Solubility, nucleation and polymerization of silica}

The solubility of silica at the pH level of 1 is $150 \mathrm{mg} / \mathrm{L}$ or $2.5 \mathrm{mmol} / \mathrm{L}$ (Alexander et al., 1954). Once the silica concentration is above this value, silica starts to nucleate and condensate. At the olivine nano-silica production conditions, $218 \mathrm{~g}$ of olivine (1.5 moles) per liter of acid are used. Once this material has reacted with the acid, 90 (stoichiometric calculations) grams of silica are released to the medium. The silica starts to condensate when the conversion degree, is $0.1664 \%$, which happens $4 \mathrm{~s}$ after the reaction has started at $90{ }^{\circ} \mathrm{C}$ (see Table 10). Therefore, it can be considered that solid particles of silica are present during the whole experiment. The primary particles formed in a silicic acid solution are around $5 \mathrm{~nm}$ (Gorrepati et al., 2010; Iler, 1979). These silica particles grow forming siloxane bonds via a condensation reaction (Iler, 1979):

$\equiv \mathrm{Si}-\mathrm{OH}+\mathrm{OH}-\mathrm{Si} \equiv \rightarrow \equiv \mathrm{Si}-\mathrm{O}-\mathrm{Si} \equiv+\mathrm{H}_{2} \mathrm{O}$.

The formation of siloxane bonds is catalyzed by the concentration of hydrogen ion (Iler, 1979). Gorrepati et al. (2010) stated that the silica particles grow over time in acidic media reaching sizes above $500 \mathrm{~nm}$. She also stated that silica particles reach a diameter of $200 \mathrm{~nm}$ after $100 \mathrm{~min}$ in an $8 \mathrm{M} \mathrm{HCl}$ solution at $5{ }^{\circ} \mathrm{C}$ with a silica concentration of $135 \mathrm{mmol} / \mathrm{L}$, while the particles need almost seven days in a $2 \mathrm{M} \mathrm{HCl}$ solution. Under the olivine nano-silica production conditions ( $3 \mathrm{M} \mathrm{H}_{2} \mathrm{SO}_{4}, T \sim 90{ }^{\circ} \mathrm{C}$, and initial and final silica concentration of 0 and $1500 \mathrm{mmol} / \mathrm{L}$, respectively), the temperature and silica concentration are much higher than in Gorrepati's experiments, except at the beginning of the experiment $(3.4 \mathrm{~min}$ passed in experiment NS-10 to release the same amount of silica that was used in Gorrepati's experiments); therefore, the polymerization kinetics should be faster once the silica is released.

4.2.2 Literature review on solid layers on the surface of olivine grains

The formation or lack thereof of a solid layer around the olivine particles is of great interest when tackling the kinetics of the dissolution of olivine since slows down or passivates the dissolution process. The formation of a solid layer has been investigated by many authors (Bearat et al., 2006; Daval et al., 2011; Giammar et al., 2005; Grandstaff, 1986; Johnson et al., 2014; Jonckbloedt, 1997; Park and Fan, 2004; Pokrovsky and Schott, 2000a, 2000b; Safari et al., 2009; Schott and Berner, 1983; Sissmann et al., 2013; Stockmann et al., 2011; Van Herk et al., 1989). Table 11 summarizes different studies about the dissolution of olivine where a solid layer was investigated.
A solid layer was only found by Schott and Berner (1983), Van Herk et al., (1989), Bearat et al., (2006) and Sissmann et al., (2013) in a stirred reactor using SEM, TEM or X-ray photoelectron spectroscopic (XPS) techniques. Schott found a thin layer of $10 \AA$ that was unstable and did not grow over time; he also stated that this layer did not inhibit the diffusion. Van Herk found a solid layer partly covering some of the olivine grains. Bearat also found a passivating solid layer and that the passivation effect of the solid layer could be decreased by increasing the abrasion between the particles. In the same study (Bearat et al., 2006), the influence of the solid content on the conversion degree was studied, concluding that the conversion increased up to a solid content of $10 \mathrm{wt} . \%$, after which it remained constant. The fact that the conversion remained constant implies that either the solid layer was completely removed or its passivating effect was constant and, therefore, incapable of being reduced any further by abrasion.

\subsubsection{Surface characterization of olivine before and after the dissolution}

SEM images were taken from GL50 grains before and after dissolution with and without stirring. The silica layer, detected by EDS analysis, can be visually identified because (1) the surface of olivine has a different texture than the surface of silica and (2) the silica layer exhibits shrinking cracks formed during the drying of the material. The molar ratio between metal ions and silicon ( $\mathrm{Me} / \mathrm{Si}$ ) for an olivine grain is 2 , and it would be 0 for a pure and thick silica layer. Layers with shrinking cracks exhibit ratios between 0.2 and 1.8. Values close to zero correspond to silica layers with a thickness of at least the excitation depth of the electron beam. Values close to 1.8 correspond to silica layers much thinner than the excitation depth; that is because the material below the superficial layer is also taken into account in the EDS analysis.

Fig. 5 shows SEM pictures of GL50 prior to dissolution, where the presence of particles smaller than $10 \mu \mathrm{m}$ can be observed. These particles are not olivine and contribute greatly to the specific surface area. Fig. 6a-d depicts images of the olivine grains after dissolution in an unstirred reactor. The presence of a silica layer on the surface of olivine can be observed in all the images, which is representative for most grains examined in this sample. Fig. 6c and $\mathrm{d}$ were taken from the same spot but with different angles and magnifications. The thickness of the silica is larger than $700 \mathrm{~nm}$ for the grain in Fig. 6c and d.

Fig. 7a-e shows the olivine grains after dissolution in a stirred reactor. Etch pits and dissolution cracks can be observed in Fig. 7a and $b$. The presence of these features is indicative for a dissolution mechanism controlled by surface reaction (Drever, 1988). Silica layers could not be perceived by SEM on most of the grains examined, and on the rare cases, where they were observed, they did not completely cover the olivine grains. Fig. $7 c$ and $d$ are examples of these cases where a sheet silicate is in the matrix of olivine as an intergrowth, and the sheet silicate behaves as a shelter for the silica.

Table 11

Summary of the studies where the presence of a solid layer around the olivine particles was investigated.

\begin{tabular}{|c|c|c|c|c|c|c|}
\hline Solid content $(\mathrm{g} / \mathrm{L})$ & $\mathrm{pH}$ & Stirring & Solid layer & SEM/TEM & $\theta(\mathrm{nm})$ & Reference \\
\hline 250 & -0.7 to 0 & $\mathrm{~N}$ & $\mathrm{Y}$ & $\mathrm{Y}$ & - & Jonckbloedt (1997) \\
\hline 250 & -0.7 to 1 & $\mathrm{Y}$ & $\mathrm{N}$ & $\mathrm{Y}$ & - & Jonckbloedt (1997) \\
\hline 6 & $1-6$ & $\mathrm{Y}$ & $\mathrm{Y}$ & XPS & 1 & Schott and Berner (1983) \\
\hline 2 & $1-4.5$ & $\mathrm{Y}$ & $\mathrm{N}$ & $\mathrm{Y}$ & - & Grandstaff (1986) \\
\hline 4 & $1-3$ & $\mathrm{Y}$ & $\mathrm{Y}$ & Y & - & (Van Herk et al., 1989) \\
\hline- & $\mathrm{CO}_{2} 135$ bar & $\mathrm{Y}$ & $\mathrm{Y}$ & $\mathrm{Y}$ & - & Bearat et al. (2006) \\
\hline $4-16$ & $1-8$ & $\mathrm{Y}$ & $\mathrm{N}$ & $\mathrm{Y}$ & - & Pokrovsky and Schott (2000b) \\
\hline $50-100$ & $3-10$ & MS & $\mathrm{Y}$ & XPS & $<2$ & Pokrovsky and Schott (2000a) \\
\hline- & $\mathrm{CO}_{2} 1-100$ bar & $\mathrm{N}$ & $\mathrm{N}$ & $\mathrm{Y}$ & - & Giammar et al. (2005) \\
\hline- & - & $\mathrm{N}$ & $\mathrm{Y}$ & $\mathrm{Y}$ & - & Park and Fan (2004) \\
\hline 100 & $\mathrm{CO}_{2} 200 \mathrm{bar}$ & $\mathrm{N}$ & $\mathrm{Y}$ & $\mathrm{Y}$ & $<40$ & Daval et al. (2011) \\
\hline 16 & $\mathrm{CO}_{2} 280$ bar & $\mathrm{Y}$ & $\mathrm{Y}$ & $\mathrm{Y}$ & $30-50$ & Sissmann et al. (2013) \\
\hline
\end{tabular}



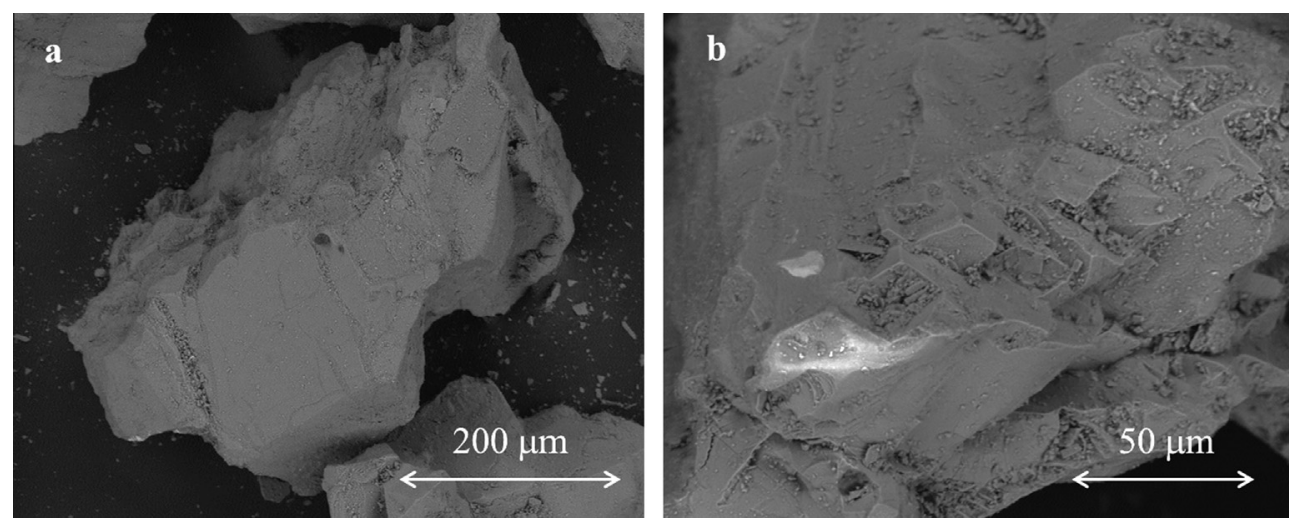

Fig. 5. (a and b) SEM pictures of dunite GL50 prior to dissolution.
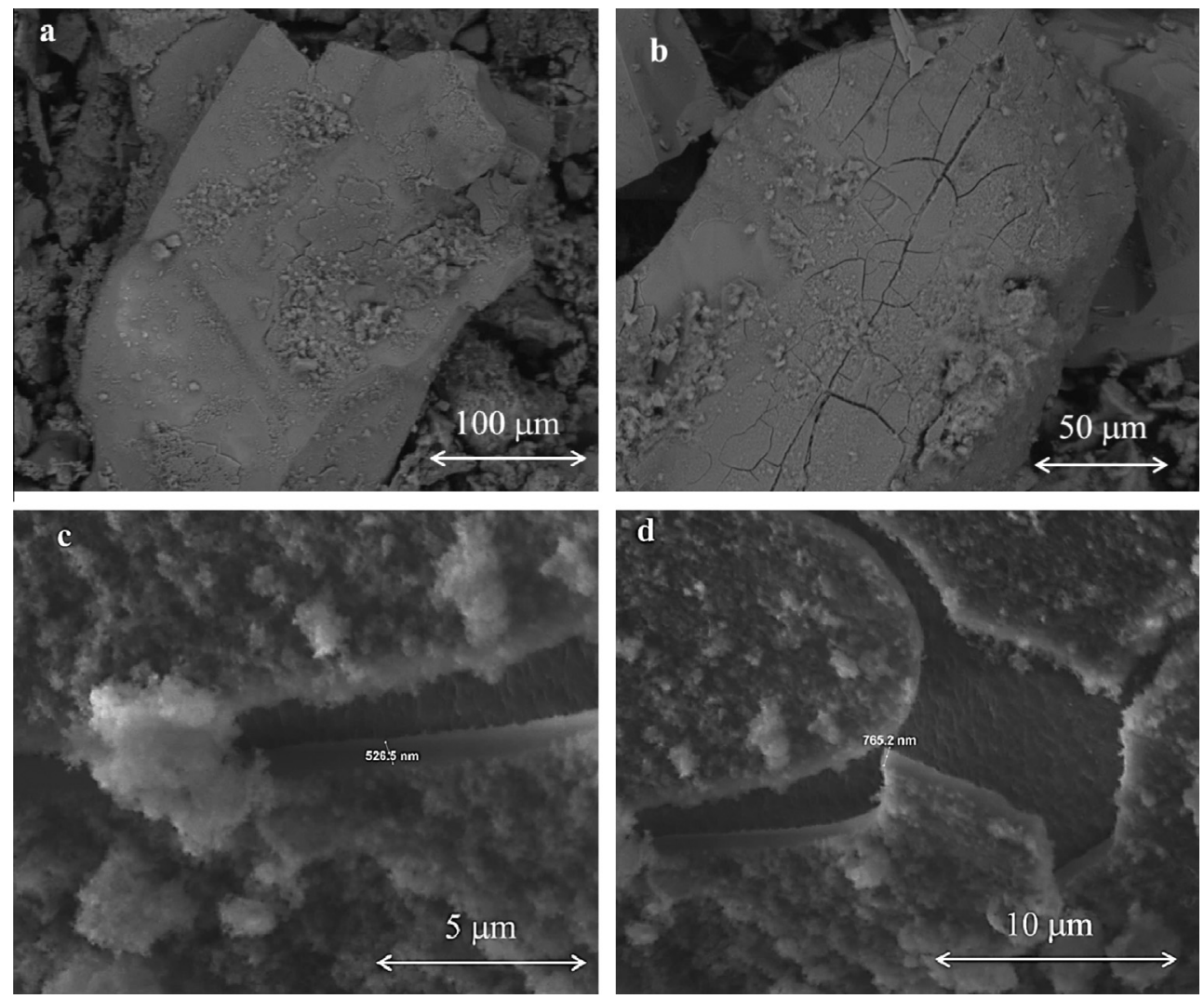

Fig. 6. (a-d) SEM pictures of GL50 after dissolution in an unstirred reactor. The thickness of the silica layer in figures c and d was 500 and 700 nm, respectively.

Fig. 7e shows an exfoliated sheet silicate that offers a protecting area to the silica particles from the stirring action.

To conclude, silica layers observed by SEM cover the surface of olivine only on rare occasions when the slurry was vigorously stirred. Under these mixing conditions, silica is removed from the surface of olivine. The detachment of the silica layer from the olivine grains depends on the fluid and mixing properties, and the $\mathrm{pH}$ of the slurry. The increase of the solid content improves the abrasion, detaching the silica layer from the olivine (Bearat et al., 2006; Park and Fan, 2004). In addition, at low pH, the polymerization of silica is enhanced (Gorrepati et al., 2010; Iler, 1979) increasing the removal of the silica layer as well. Under the olivine nano-silica production conditions, the presence of a silica layer is more unlikely than in the studies reported in the literature because (1) the solid content is higher, and, therefore, the abrasion, and (2) the polymerization is faster. In addition, the no presence of silica around the olivine grains under the experimental conditions employed here was also confirmed by Jonckbloedt (1997). The presence of nano silica layers around the olivine particles cannot be excluded using SEM, but according to Sissman (Sissmann et al., 2013), in the case that they were present, this layer would not have a passivating effect at very acidic $\mathrm{pH}$.

\subsection{Overall resistance}

The overall hydrogen ion flux is in the range of $1.82 \cdot 10^{-9}$ to $1.31 \cdot 10^{-10}$ and $3.12 \cdot 10^{-8}$ to $1.28 \cdot 10^{-9} \mathrm{~mol} \mathrm{~cm}^{-2} \mathrm{~s}^{-1}$ for experiments NS-2 and NS-10 at the beginning and at the end of the reaction (see Table 12), respectively. The slowest hydrogen ion flux through the fluid film at the beginning and at the end of the reaction, calculated in Table 8 , is $10^{-5}$ and $2 \cdot 10^{-6} \mathrm{~mol} \mathrm{~s}^{-1} \mathrm{~cm}^{-2}$, respectively. Thus, the resistance due to the liquid film can be 

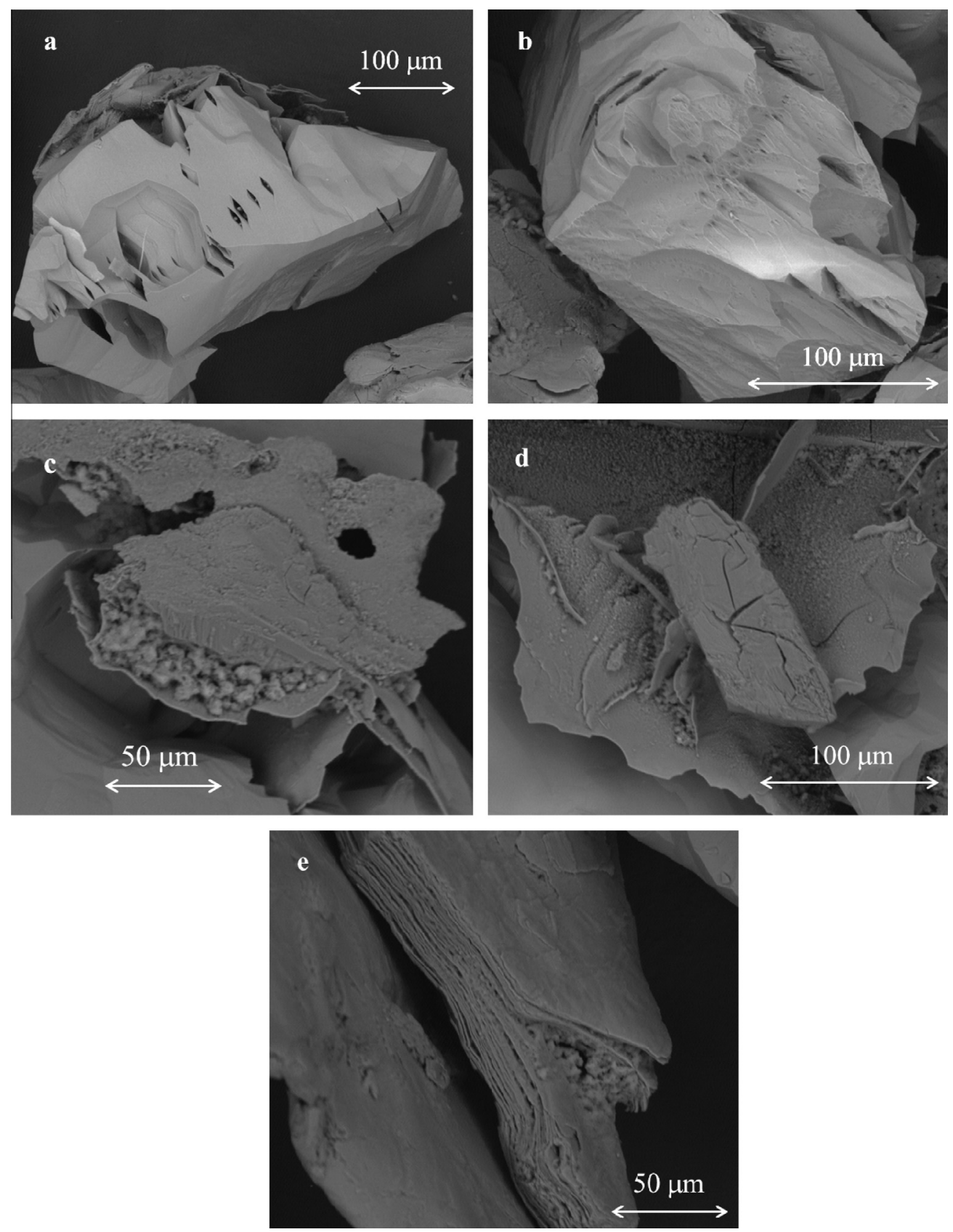

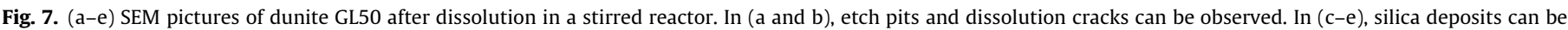
found in protected sites offered by an inert (or slower) silicate mineral.

neglected because the transport through it is much faster than the overall flux. The resistance due to the solid layer could not be neglected in the case that a solid layer would actually exist and the value of $D_{e}$ would be $3 \cdot 10^{-22} \mathrm{~m}^{2} \mathrm{~s}^{-1}$ or smaller. However, the presence of a thick (or SEM visible) silica layer under the olivine nano-silica process conditions is unlikely due to the vigorous agitation, high solid content ( $250 \mathrm{~g} / \mathrm{L})$ and strongly acidic medium, which improves the abrasion and increases the polymerization of silica. SEM pictures of the olivine grains show that only on rare occasions the olivine grains were partly covered by silica. In addition, etch pits and dissolutions cracks were also found in these pictures, which are indicative of a rate controlled by surface reaction (Drever, 1988). Thus, it can be considered that the overall flux is controlled only by the surface reaction. In the case that a passivating solid layer would cover the olivine grains, which is unlikely, the overall flux would involve both steps, the surface reaction and the diffusion through the solid layer.

\subsection{Surface reaction model}

The surface reaction model proposed here consists of basically two parts: (1) the shrinking core model and specific surface area of olivine; and (2) the mass balance. In addition to them, the hydrogen ion activity was calculated using the PHREEQC model (Parkhurst and Appelo, 1999). More details about these activity calculations are given in Appendix I.

\subsubsection{Shrinking core model and specific surface area}

The specific surface area is calculated with the Brantley equation using the geometric particle size distribution $\left(\mathrm{PSD}_{\mathrm{G}}\right)$. Because 
Table 12

Species flux for experiments NS-2 and NS-10 at the beginning and at the end of the reaction.

\begin{tabular}{|c|c|c|c|c|c|c|}
\hline Sample & Fraction $_{\mathrm{O} 1}(\mu \mathrm{m})$ & $T_{r}\left({ }^{\circ} \mathrm{C}\right)$ & $N_{\mathrm{ol}, 1}\left(\mathrm{~mol} \mathrm{~s}^{-1} \mathrm{~cm}^{-2}\right)$ & $N_{\mathrm{ol}, 2}\left(\mathrm{~mol} \mathrm{~s}^{-1} \mathrm{~cm}^{-2}\right)$ & $N_{\mathrm{H}, 1}\left(\mathrm{~mol} \mathrm{~s}^{-1} \mathrm{~cm}^{-2}\right)$ & $N_{\mathrm{H}, 2}\left(\mathrm{~mol} \mathrm{~s}^{-1} \mathrm{~cm}^{-2}\right)$ \\
\hline NS-2 & $150-250$ & 52.0 & $4.54 \mathrm{E}-10$ & $3.27 \mathrm{E}-11$ & $1.82 \mathrm{E}-09$ & $1.31 \mathrm{E}-10$ \\
\hline NS-10 & $150-250$ & 89.8 & $7.80 \mathrm{E}-09$ & $3.21 \mathrm{E}-10$ & $3.12 \mathrm{E}-08$ & $1.28 \mathrm{E}-09$ \\
\hline
\end{tabular}

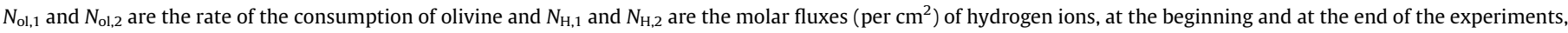
respectively.

Table 13

Experimental conditions of dissolution of dunites in $3 \mathrm{M}$ sulfuric acid.

\begin{tabular}{|c|c|c|c|c|c|c|c|}
\hline Sample & Dunite & $d_{A}(\mu \mathrm{m})$ & Fraction $(\mu \mathrm{m})$ & $\mathrm{SSA}_{\mathrm{Br}}{ }^{\mathrm{a}}\left(\mathrm{m}^{2} / \mathrm{g}\right)$ & $T_{r}\left({ }^{\circ} \mathrm{C}\right)$ & Ratio $\mathrm{H}^{+} / \mathrm{Ol}$ & $V_{\mathrm{H}_{2} \mathrm{SO}_{4}}(\mathrm{~L})$ \\
\hline NS-1 & CRS-US & 138 & $125-150$ & 0.068 & 48.7 & 4.5 & 0.5 \\
\hline NS-2 & CRS-US & 200 & $150-250$ & 0.045 & 52.0 & 4.0 & 0.5 \\
\hline NS-3 & CRS-US & 400 & $300-500$ & 0.023 & 55.0 & 3.8 & 0.5 \\
\hline NS-4 & CRS-US & 200 & $150-250$ & 0.045 & 70.2 & 4.0 & 0.5 \\
\hline NS-5 & CRS-US & 400 & $300-500$ & 0.023 & 70.7 & 4.0 & 0.5 \\
\hline NS-7 & CRS-US & 275 & $250-300$ & 0.032 & 87.7 & 4.2 & 0.5 \\
\hline NS-8 & CRS-US & 400 & $300-500$ & 0.023 & 86.2 & 4.1 & 0.5 \\
\hline NS-9 & CRS-US & 200 & $150-250$ & 0.045 & 50.6 & 4.1 & 0.5 \\
\hline NS-10 & CRS-US & 200 & $150-250$ & 0.045 & 89.8 & 4.2 & 0.5 \\
\hline NS-11 & GL50 & 302 & $250-355$ & 0.034 & 90.0 & 4.2 & 0.5 \\
\hline NS-12 & GL50 & 302 & $250-355$ & 0.034 & 89.7 & 4.1 & 0.5 \\
\hline NS-13 & GL50 & 302 & $250-355$ & 0.034 & 89.9 & 4.1 & 0.5 \\
\hline NS-14 & GL50 & 300 & $100-500$ & 0.038 & 70.2 & 4.3 & 10 \\
\hline
\end{tabular}

${ }^{a} \mathrm{SSA}_{\mathrm{Br}}$ prior to dissolution. The term $d_{A}$ refers to the average particle size obtained from sieving, fraction the olivine fraction used and ratio $\mathrm{H}^{+} / \mathrm{Ol}$ the molar ratio of hydrogen ion to olivine.

the fraction dissolved is in the range of $0-99 \%$, the specific surface area of olivine significantly changes over time. Therefore, a shrinkage model should be used that takes into account the particle size reduction. The best model in this case, where no solid layer is involved, is the shrinking particle (see Fig. 2). The particle size reduction $(\Delta R)$ as a function of the olivine consumed, considering spherical particles, can be described by:

$\Delta R=\sqrt[3]{\frac{3}{16 \cdot \pi} \cdot \frac{n_{\mathrm{H}_{\mathrm{con}}^{+}} \cdot M_{\mathrm{ol}}}{\rho_{\mathrm{ol}}}}=1.3921 \cdot \sqrt[3]{n_{\mathrm{H}_{\mathrm{con}}^{+}}}$,

where $n_{\mathrm{H}_{\mathrm{con}}^{+}}$is the number of hydrogen ions consumed by the olivine and $M_{\mathrm{ol}}$ the molar mass of olivine. Using this equation, the $\mathrm{PSD}_{\mathrm{G}}$ with the conversion degree can be obtained and, likewise, the $\mathrm{SSA}_{\mathrm{Br}}$. However, the equation proposed by Brantley was obtained for laboratory-ground primary silicates and not for weathered silicates. Because there is no better alternative to estimate the SSA of weathered olivine, the $\mathrm{SSA}_{\mathrm{Br}}$ equation is employed here. In addition, the use of the Brantley equation (see Eq. (4)) gives erroneous values when most of the olivine (above $80 \%$ ) is consumed. The cause of this is a calculation issue that appears because: (1) a discrete particle size distribution is used; (2) the difference between $\Delta R$ and $R$ is extremely small, which gives an extraordinary high surface area; and (3) the Brantley equation is logarithmic. Fig. 8 shows the variation of the relative roughness surface area, $\lambda / \lambda_{i}$, with the olivine consumed, where the calculation problem can be observed when the olivine consumed is above $80 \%$. An expression that determines the $\lambda$ without this problem can be obtained by fitting the relative roughness surface below $80 \%$ of the olivine consumed $\left(m_{\mathrm{ol} \_c o n}\right)$ to a polynomial equation and multiplying it by the initial (prior to dissolution) roughness factor:

$\lambda=\lambda_{i} \cdot\left[A \cdot\left(m_{\mathrm{ol} \_ \text {con }}\right)^{5}+B \cdot\left(m_{\mathrm{ol} \_ \text {con }}\right)^{4}+C \cdot\left(m_{\mathrm{ol} \_ \text {con }}\right)^{3}\right.$

$$
\left.+D \cdot\left(m_{\text {ol_con }}\right)^{2}+E \cdot\left(m_{\text {ol_con }}\right)^{2}+1\right],
$$

being the $A=2.9795 \cdot 10^{-09}, B=-5.2239 \cdot 10^{-07}, C=3.2821 \cdot 10^{-05}$, $D=-8.2023 \cdot 10^{-04}$ and $E=8.0935 \cdot 10^{-03}$. Because the relative roughness surface areas show similar trends, this equation can be used to calculate the roughness factor for all the dunite fractions used in the dissolution experiments after shrinking. Therefore, using Eq. (20), the specific surface area for all the different PSD of olivine during the reaction can be estimated.

It is remarkable that the relative roughness surface area $\left(\lambda / \lambda_{i}\right)$ shown in Fig. 8 slightly increases with the mass of olivine consumed (i.e., the conversion degree), whereas the expected trend for $\lambda / \lambda_{i}$ of silicates should be a decrease with the conversion degree. This difference is not only because the Brantley equation was obtained for laboratory-ground primary silicates, but also because this equation considers that $\lambda$ is dependent on the grain size.

\subsubsection{Mass balance}

In addition to the specific surface area of the shrinking cores, a mass balance is required in order to develop a model for the experimental data of the hydrogen ion concentration. A mass balance over the hydrogen ions results in:

$\left[\mathrm{H}^{+}\right](t)=\left[\mathrm{H}^{+}\right]_{i}-(4 \cdot r \cdot \mathrm{SSA}) \cdot \Delta t$,

where $\left[\mathrm{H}^{+}\right]$is the hydrogen ion concentration, $r$ the dissolution rate, SSA the specific surface area of olivine and $t$ the time.

The model proposed in here studies the changes of the hydrogen ion concentration with time. The programming language used to develop the model was Visual Basic. This model includes three parts: the mass balance of the hydrogen ion (Eq. (21)), the shrinking core model of the olivine grains (Eq. (19)) and the olivine dissolution kinetics (Eq. (2)). The experimental variables of this model are the specific surface area of olivine, the reaction temperature and the hydrogen ion activity. The model factors that need to be calculated from the fitting to the experimental data are the kinetic parameters $k_{T}$ and $n$.

\section{Results}

\subsection{Experimental conditions}

The variables of the dissolution experiments are the specific surface area and temperature (see Table 13). The concentration of hydrogen ion was set at the beginning of the experiment as $6 \mathrm{M}$. In addition, two types of commercial dunites, both originating from Norway, were used to check if their dissolution behavior was similar. 


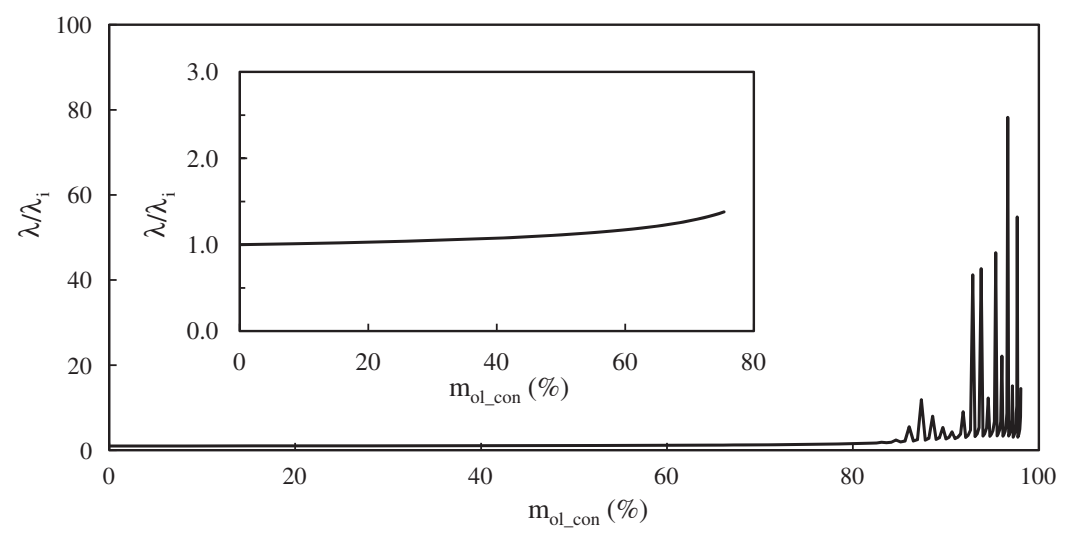

Fig. 8. Variation of the relative roughness surface area, $\lambda / \lambda_{i}$, with the olivine consumed for experiment NS-4.

\subsection{Kinetic model}

The kinetic parameters, $k_{T}$ and $n$ (see Eq. (2)), can be obtained by fitting the model based on Eq. (21) to the experimental results. For each dissolution experiment, a set of parameters that minimize the square error between the kinetic model and the experimental data was obtained. Fig. 9 shows the experimental data and two calculated dissolution curves for the $n$ values of 0.35 and 0.5 , and a rate constant of $3.45 \cdot 10^{-9}\left(\mathrm{~mol} \mathrm{~cm}^{-2} \mathrm{~s}^{-1}\right)$ for experiment NS-8. The calculated dissolution curve of $n=0.5$ gives better results than the curve of 0.35 .

Table 14 lists the values of $k_{T}$ and $n$ that produced the best fit for experiments NS-1 to NS-10, where dunite CRS-US was used. The calculated dissolution curves, obtained using the best fitting values of $k_{T}$ and $n$, are shown in Appendix II. The activation energy and the pre-exponential factor can be calculated from a linear regression of the logarithm of $k_{T}$ versus the inverse of the temperature, as can be seen in Fig. 10. In this figure, experiment NS-3 was not included in the linear regression because it did not follow the general trend. The linear regression closely fits the logarithmic values resulting in a determination coefficient above $99 \%$. Working out this equation results in a pre-exponential factor of $856\left(\mathrm{~mol} \mathrm{~cm}^{-2} \mathrm{~s}^{-1}\right)$ and an activation energy of $78.5(\mathrm{~kJ} / \mathrm{mol})$ :

$r=856 \cdot \exp \left(\frac{-78.5}{R \cdot T}\right) \cdot a_{\mathrm{H}^{+}}^{0.5}$

Table 14 also lists the rate constants calculated using Eq. (22) and the error between the $k_{T_{-} \text {fit }}$ and $k_{T_{-} \text {cal }}$. The average error in $k_{T_{-} c a l}$ - excluding experiment NS-3 - is $5 \%$.

Comparing the reaction constant ( $\left.k_{T_{-} c a l}\right)$ of NS-1 and NS-10 at 49 and $90^{\circ} \mathrm{C}$, the reaction at $90^{\circ} \mathrm{C}$ is 27 times faster than at $50{ }^{\circ} \mathrm{C}$. The activation energies obtained from olivine dissolution studies are in the range $40-78.5 \mathrm{~kJ} \mathrm{~mol}^{-1}$ (see Table 1 ). At a reaction temperature of $90^{\circ} \mathrm{C}$, the required temperature rise to double the reaction rate at $40 \mathrm{~kJ} \mathrm{~mol}^{-1}$ and $78.5 \mathrm{~kJ} \mathrm{~mol}^{-1}$ are $20^{\circ} \mathrm{C}$ and $10^{\circ} \mathrm{C}$, respectively. Thus, the higher the $E_{a}$ is, the more temperature-sensitive the kinetics is. This means that the model proposed here with an $E_{a}$ of $78.5 \mathrm{~kJ} \mathrm{~mol}^{-1}$ is more sensitive to the temperature than the models in the literature (except in the study of Wogelius and Walther (1992)). Usually, chemical reactions are more temperature-sensitive than the physical steps (e.g. diffusion transport).

This kinetic model was also used with experiments NS-11 to NS-14, where dunite GL50 was employed. Table 15 presents the fitted and calculated reaction constants for these experiments as well as the error between the two values of $k_{T}$. In experiments NS-11, -12 and -13 , where the same dunite fraction was used (see Table 13), the fitted rate constant is around $8 \%$ smaller than the calculated rate constant. The error in experiment NS-14, where

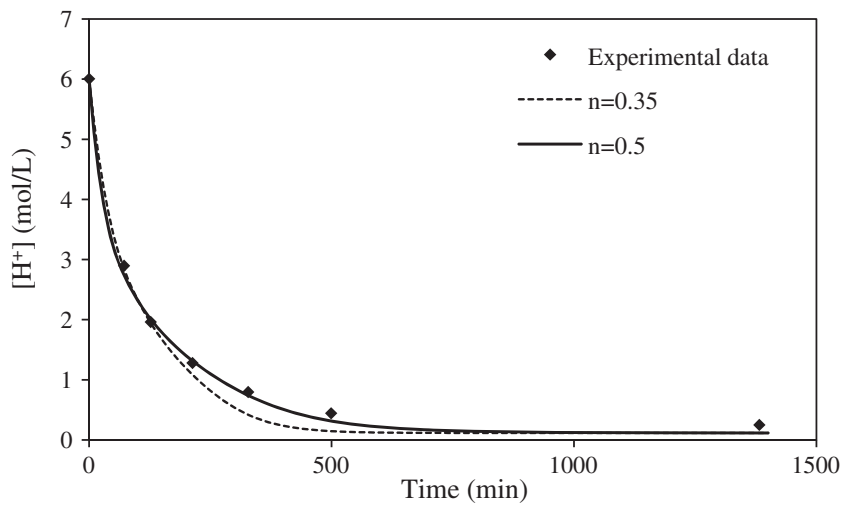

Fig. 9. Experimental data and calculated dissolution curves for different values of $n$ and $k_{T}$ value of $3.45 \cdot 10^{-9}\left(\mathrm{~mol} \mathrm{~cm}^{-2} \mathrm{~s}^{-1}\right)$ for experiment NS-8.

another dunite fraction and a reaction volume 20 times larger was used, is around $7 \%$ higher than the calculated rate constant. The average error between $k_{T}$ calculated and fitted for experiments conducted with dunite GL50 is $7.6 \%$.

\section{Discussion}

The kinetic parameters $E_{a}$ and $n$ obtained for the model proposed here are in the range found in the literature. The activation energy is slightly higher than in most of the kinetics studies (except for the work of Chen and Brantley (2000), where the $E_{a}$ is dubious as is explained before), only being above this value the $E_{a}$ reported by Wogelius and Walther (1992). Comparing with the $E_{a}$ obtained by Jonckbloedt (1997), the activation energy in the experiments performed in this study is $18 \%$ higher, which makes the developed model more temperature-sensitive than Jonckbloedt's model. The reaction order found here agrees with most of the data from the literature, but disagrees with the kinetic model of Jonckbloedt.

The reaction order of 0.5 was explained by Rosso and Rimstidt (2000) as the formation of an activated complex, where two hydrogen ions attach to each of the two bridging oxygen atoms, and, simultaneously, water molecules displace the $\mathrm{Mg}-\mathrm{O}$ bonds. This activated complex should be less rigid than the olivine structure, breaking down to aqueous species. Rimstidt et al. (2012) stated that the forsterite dissolution involves chain reactions with several elementary reaction stages. Thus, the reaction order (likewise the kinetic parameter $A$ and $E_{a}$ ) here obtained should be considered as apparent values of the overall process. 
Table 14

Values of $k_{T}$ and $n$ producing the best fitting for experiments NS-1 to NS-10 using dunite CRS-US.

\begin{tabular}{|c|c|c|c|c|c|}
\hline Experiment & $T\left({ }^{\circ} \mathrm{C}\right)$ & $n$ & $k_{T_{-} \text {fit }}\left(\mathrm{mol} \mathrm{cm}^{-2} \mathrm{~s}^{-1}\right)$ & $k_{T_{-} \text {cal }}\left(\mathrm{mol} \mathrm{cm}^{-2} \mathrm{~s}^{-1}\right)$ & Error (\%) \\
\hline NS-1 & 48.75 & 0.5 & $1.45 \mathrm{E}-10$ & $1.549 \mathrm{E}-10$ & 6.9 \\
\hline NS-2 & 52.07 & 0.5 & $2.10 \mathrm{E}-10$ & $2.090 \mathrm{E}-10$ & 0.5 \\
\hline NS-3 & 51.11 & 0.5 & $3.00 \mathrm{E}-10$ & $1.919 \mathrm{E}-10$ & 36.0 \\
\hline NS-4 & 70.21 & 0.5 & $9.30 \mathrm{E}-10$ & $9.701 \mathrm{E}-10$ & 4.3 \\
\hline NS-5 & 70.67 & 0.5 & $1.04 \mathrm{E}-09$ & $1.006 \mathrm{E}-09$ & 3.2 \\
\hline NS-7 & 88.51 & 0.5 & $4.10 \mathrm{E}-09$ & $3.901 \mathrm{E}-09$ & 4.9 \\
\hline NS-8 & 86.19 & 0.5 & $3.45 \mathrm{E}-09$ & $3.296 \mathrm{E}-09$ & 4.5 \\
\hline NS-9 & 50.57 & 0.5 & $1.95 \mathrm{E}-10$ & $1.828 \mathrm{E}-10$ & 6.3 \\
\hline NS-10 & 89.75 & 0.5 & $3.90 \mathrm{E}-09$ & $4.266 \mathrm{E}-09$ & 9.4 \\
\hline
\end{tabular}

$k_{T_{-} \text {fit }}$ is the reaction constant that produced a better fitting to the experimental results and $k_{T_{-} c a l}$ is the reaction constant obtained from Eq. (22).

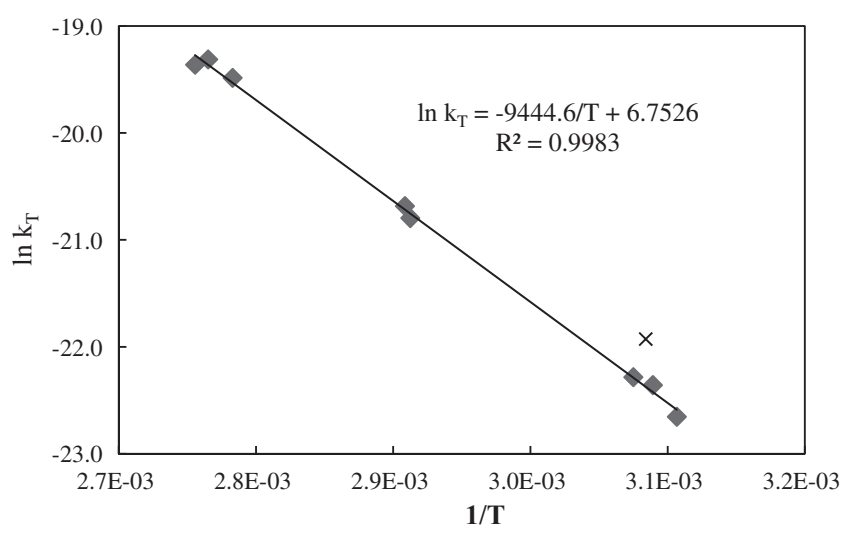

Fig. 10. Logarithm of $k_{T}$ versus the inverse of the temperature for experiments with dunite CRS-US. Experiment NS-3 is not included in the regression.

\section{Table 15}

Fitted and calculated reaction constants for experiments with dunite GL50 and the error between these two $k_{T}$.

\begin{tabular}{lllll}
\hline Exp. & $T\left({ }^{\circ} \mathrm{C}\right)$ & $k_{T_{-} \text {fit }}\left(\mathrm{mol} \mathrm{cm}^{-2} \mathrm{~s}^{-1}\right)$ & $k_{T_{-} \text {cal }}\left(\mathrm{mol} \mathrm{cm}^{-2} \mathrm{~s}^{-1}\right)$ & Error $(\%)$ \\
\hline NS-11 & 90.0 & $3.950 \mathrm{E}-09$ & $4.343 \mathrm{E}-09$ & 9.96 \\
NS-12 & 89.7 & $4.000 \mathrm{E}-09$ & $4.253 \mathrm{E}-09$ & 6.34 \\
NS-13 & 89.9 & $4.020 \mathrm{E}-09$ & $4.319 \mathrm{E}-09$ & 7.44 \\
NS-14 & 70.2 & $1.040 \mathrm{E}-09$ & $9.691 \mathrm{E}-10$ & 6.81 \\
\hline
\end{tabular}

The rate constant and the dissolution rate, calculated with the model developed, at $25^{\circ} \mathrm{C}$ and $\mathrm{pH}$ of 2 are $k_{T_{-} \text {cal }}=1.51 \cdot 10^{-11}$ and $r=1.51 \cdot 10^{-12}\left(\mathrm{~mol} \mathrm{~cm}^{-2} \mathrm{~s}^{-1}\right)$. The dissolution rate agrees with the results from the literature showing the validity of the kinetic model. Unfortunately, the dissolution rate of the model proposed here cannot be compared with the one of Jonckbloedt because he did not report the $\mathrm{SSA}_{\mathrm{G}}$. The kinetic model developed (obtained using dunite CRS-US) can also be used for dunite GL50 with an average error of $7.6 \%$. In addition, an experiment with a reaction volume 20-times larger (NS-14) was also well described by Eq. (22), confirming the robustness of the model.

\section{Conclusion}

The silica released during the dissolution of olivine in acid forms a silica layer over the olivine grains when the reactor was not stirred. When the reactor was vigorously stirred, visible silica layers by SEM could only be observed on the olivine surface (and only partially covering the surface of the grains) on rare occasions. Therefore, under these conditions the diffusion transport through a solid layer is not the limiting step.

Several assumptions have been made in the model proposed here about the dissolution of olivine under the extreme conditions for nano-silica production such as: (1) the process is not controlled by the diffusion through a solid layer but by the surface reaction; (2) the olivine particles shrink over time as the shrinking particle model describes (Fig. 2a); and (3) the specific surface area of olivine can be estimated using the roughness factor based on the Brantley equation. From the good correlation between the experimental data and the proposed model it can be inferred that the assumptions made are reasonable.

In this study an activation energy of $78.5 \mathrm{~kJ} / \mathrm{mol}$ and a reaction order of 0.5 were obtained. This activation energy is slightly higher than that reported in most kinetics studies. The dissolution rate and rate constant at $\mathrm{pH}$ value of 2 and $25^{\circ} \mathrm{C}$ are $1.5 \cdot 10^{-12}$ mol cm $\mathrm{cm}^{-2} \mathrm{~s}^{-1}$ and $1.5 \cdot 10^{-11} \mathrm{~mol} \mathrm{~cm}{ }^{-2} \mathrm{~s}^{-1}$, respectively, which are comparable to the values found in the literature. The average error between $k_{T_{-} c a l}$ and $k_{T_{-} f i t}$ is $5 \%$, which shows a good agreement between the present model and the olivine dissolution experiments for dunite CRS-US. The average error of $k_{T_{-} \text {cal }}$ for dissolution experiments performed with dunite GL50 is slightly higher (7.6\%).

This kinetic model can be applied, with good accuracy, to predict the olivine dissolution under the nano-silica production conditions for other dunite materials than those used in this work, and for other reaction volumes. Therefore, it can be used in the industrial production of nano-silica to predict the evolution of the conversion over time. Additionally, a similar approach could be used to study the kinetics and the rate-limiting step of the transport of other processes such as the leaching of other type of silicates.

\section{Acknowledgements}

The authors wish to express their appreciations to Mr. R.J. van Enk, Mr. J. Nokes, Dr. G. Quercia, Mr. C. Straub and Dr. A.J.J. Zanden for the fruitful discussions and comments. They furthermore express their gratitude to EU FP7 project ProMine: Nano-particle products from new mineral resources in Europe (Grant Agreement No. 228559). The authors wish to express their gratitude to the following sponsors of the Building Materials research group at TU Eindhoven: Rijkswaterstaat Grote Projecten en Onderhoud, Graniet-Import Benelux, Kijlstra, Betonmortel, Struyk Verwo, Attero, Enci, Provincie Overijssel, Rijkswaterstaat Zee en Delta-District Noord, Van Gansewinkel Minerals, BTE, V.d. Bosch Beton, Selor, Twee "R" Recycling, GMB, Schenk Concrete Consultancy, Geochem Research, Icopal, BN International, Eltomation, Knauf Gips, Hess AAC Systems, Kronos, Joma, CRH Europe Sustainable Concrete Centre, Cement\&BetonCentrum, Heros (in chronological order of joining).

\section{Appendix A. Supplementary material}

Supplementary data associated with this article can be found, in the online version, at http://dx.doi.org/10.1016/j.apgeochem.2014. 10.015 . 


\section{References}

Alexander, G.B., Heston, W.M., Iler, R.K., 1954. The solubility of amorphous silica in water. J. Phys. Chem. 58, 453-455.

Awad, A., Koster van Groos, A.F., Guggenheim, S., 2000. Forsteritic olivine: effect of crystallographic direction on dissolution kinetics. Geochim. Cosmochim. Acta 64, 1765-1772.

Bearat, H., McKelvy, M.J., Chizmeshya, A.V.G., Gormley, D., Nunez, R., Carpenter, R.W., Squires, K., Wolf, G.H., 2006. Carbon sequestration via aqueous olivine mineral carbonation: role of passivating layer formation. Environ. Sci. Technol. 40, 4802-4808

Blum, A., Lasaga, A., 1988. Role of surface speciation in the low-temperature dissolution of minerals. Nature 331, 431-433.

Brantley, S.L., Mellott, N.P., 2000. Surface area and porosity of primary silicate minerals. Am. Mineral. 85, 1767-1783.

Casey, W.H., Banfield, J.F., Westrich, H.R., McLaughlin, L., 1993. What do dissolution experiments tell us about natural weathering? Chem. Geol. 105, 1-15.

Chen, Y., Brantley, S.L., 2000. Dissolution of forsteritic olivine at $65^{\circ} \mathrm{C}$ and $2<\mathrm{pH}<5$. Chem. Geol. 165, 267-281.

Daval, D., Testemale, D., Recham, N., Tarascon, J.M., Siebert, J., Martinez, I., Guyot, F., 2010. Fayalite $\left(\mathrm{Fe}_{2} \mathrm{SiO}_{4}\right)$ dissolution kinetics determined by X-ray absorption spectroscopy. Chem. Geol. 275, 161-175.

Daval, D., Sissmann, O., Menguy, N., Saldi, G.D., Guyot, F., Martinez, I., Corvisier, J. Garcia, B., Machouk, I., Knauss, K.G., Hellmann, R., 2011. Influence of amorphous silica layer formation on the dissolution rate of olivine at $90{ }^{\circ} \mathrm{C}$ and elevated $\mathrm{pCO}_{2}$. Chem. Geol. 284, 193-209.

Daval, D., Hellmann, R., Martinez, I., Gangloff, S., Guyot, F., 2013. Lizardite serpentine dissolution kinetics as a function of $\mathrm{pH}$ and temperature, including effects of elevated $\mathrm{pCO}_{2}$. Chem. Geol. 351, 245-256.

Declercq, J., Bosc, O., Oelkers, E.H., 2013. Do organic ligands affect forsterite dissolution rates? Appl. Geochem. 39, 69-77.

Drever, J., 1988. The Geochemistry of Natural Waters. Prentice-Hall.

Duro, L., El Aamrani, F., Rovira, M., Gimenez, J., Casas, I., de Pablo, J., Bruno, J., 2005. The dissolution of high-FeO olivine rock from the Lovasjärvi intrusion (SEFinland) at $25^{\circ} \mathrm{C}$ as a function of pH. Appl. Geochem. 20, 1284-1291.

Ferruzzi, G.G., 1993. The Character and Rates of Dissolution of Pyroxenes and Pyroxenoids (MS Thesis). University of California.

Freedonia, 2012. World Specialty Silicas.

Garcia, B., Beaumont, V., Perfetti, E., Rouchon, V., Blanchet, D., Oger, P., Dromart, G., Huc A.Y., Haeseler, F., 2010. Experiments and geochemical modelling of $\mathrm{CO}_{2}$ sequestration by olivine: potential, quantification. Appl. Geochem. 25, 1383-1396.

Giammar, D.E., Bruant, J., Peters, C.A., 2005. Forsterite dissolution and magnesite precipitation at conditions relevant for deep saline aquifer storage and sequestration of carbon dioxide. Chem. Geol. 217, 257-276.

Gorrepati, E.A., Wongthahan, P., Raha, S., Fogler, H.S., 2010. Silica precipitation in acidic solutions: mechanism, pH effect, and salt effect. Langmuir 26, 10467-10474.

Grandstaff, D.E., 1978. Changes in surface area and morphology and the mechanism of forsterite dissolution. Geochim. Cosmochim. Acta 42, 1899-1901.

Grandstaff, D.E., 1986. The dissolution rate of forsteritic olivine from Hawaiian beach sand. In: Colman, S.M., Dethier, D.P. (Eds.), Rates of Chemical Weathering of Rocks and Minerals. Academic Press Inc, Orlando, pp. 41-59.

Hänchen, M., Prigiobbe, V., Storti, G., Seward, T.M., Mazzotti, M., 2006. Dissolution kinetics of fosteritic olivine at $90-150{ }^{\circ} \mathrm{C}$ including effects of the presence of $\mathrm{CO}_{2}$. Geochim. Cosmochim. Acta 70, 4403-4416.

Haug, T.A., Kleiv, R.A., Munz, I.A., 2010. Investigating dissolution of mechanically activated olivine for carbonation purposes. Appl. Geochem. 25, 1547-1563.

Huijgen, W.J., Witkamp, G.J., Comans, R.N., 2005. Mineral $\mathrm{CO}_{2}$ sequestration by steel slag carbonation. Environ. Sci. Technol. 39, 9676-9682.

Iler, R.K., 1979. The Chemistry of Silica: Solubility, Polymerization, Colloid and Surface Properties, and Biochemistry. John Wiley \& Sons.

Johnson, N.C., Thomas, B., Maher, K., Rosenbauer, R.J., Bird, D., Brown, J., 2014. Olivine dissolution and carbonation under conditions relevant for in situ carbon storage. Chem. Geol. 373, 93-105.

Jonckbloedt, R.C.L., 1997. The Dissolution of Olivine in Acid, a Cost Effective Process for the Elimination of Waste Acids. Utrecht University.

Jonckbloedt, R.C.L. 1998. Olivine dissolution in sulphuric acid at elevated temperatures-implications for the olivine process, an alternative waste acid neutralizing process. J. Geochem. Explor. 62, 337-346.

King, H.E., Plümper, O., Putnis, A., 2010. Effect of secondary phase formation on the carbonation of olivine. Environ. Sci. Technol. 44, 6503-6509.

Kleiv, R.A., Thornhill, M., 2011. Dry magnetic separation of olivine sand. Physicochem. Probl. Miner. Process 47, 213-228.

Lazaro, A., Brouwers, H.J.H., Quercia, G., Geus, J.W., 2012. The properties of amorphous nano-silica synthesized by the dissolution of olivine. Chem. Eng. J. 211-212, 112-121.
Lazaro, A., Quercia, G., Brouwers, H.J.H., Geus, J.W., 2013a. Synthesis of a green nano-silica material using beneficiated waste dunites and its application in concrete. World J. Nano Sci. Eng. 3, 41-51.

Lazaro, A., Van de Griend, M.C., Brouwers, H.J.H., Geus, J.W., 2013b. The influence of process conditions and Ostwald ripening on the specific surface area of olivine nano-silica. Microporous Mesoporous Mater. 181, 254-261.

Levenspiel, O., 1999. Chemical Reaction Engineering. John Wiley \& Sons.

Levins, D.M., Glastonbury, J.R., 1972. Particle-liquid hydrodynamics and mass transfer in a stirred vessel. Part II: Mass transfer. Trans. Inst. Chem. Eng. - Lond. $50,132-146$.

Liddell, K.C., 2005. Shrinking core models in hydrometallurgy: what students are not being told about the pseudo-steady approximation. Hydrometallurgy 79, 62-68.

Lide, D.R., 2009. CRC Handbook of Chemistry and Physics. CRC Press/Taylor and Francis, Boca Raton, FL.

Lieftink, D.J., 1997. The Preparation and Characterization of Silica from Acid Treatment of Olivine. Utrecht University.

Lieftink, D.J., Geus, J.W., 1998. The preparation of silica from the olivine process and its possible use as a catalyst support. J. Geochem. Explor. 62, 347-350.

Oelkers, E.H., 2001. An experimental study of forsterite dissolution rates as a function of temperature and aqueous $\mathrm{Mg}$ and Si concentrations. Chem. Geol, $175,485-494$

Olsen, A.A., Donald Rimstidt, J., 2008. Oxalate-promoted forsterite dissolution at low pH. Geochim. Cosmochim. Acta 72, 1758-1766.

Osland, R., 1997. Modelling of Variation is Norwegian Olivine Deposits (Causes of Variation and Estimation of Key Quality Factors). Norwegian University of Science and Technology.

Park, A.H.A., Fan, L.S., 2004. Mineral sequestration: physically activated dissolution of serpentine and pH swing process. Chem. Eng. Sci. 59, 5241-5247.

Parkhurst, D.L., Appelo, C.A.J., 1999. User's Guide to PHREEQC (Version 2): A Computer Program for Speciation, Batch-reaction, One-dimensional Transport, and Inverse Geochemical Calculations. US Geological Survey Denver.

Paul, E.L., Atiemo-Obeng, V., Kresta, S.M., 2004. Handbook of Industrial Mixing: Science and Practice. Wiley. com.

Perry, R.H., Green, D.W., 2008. Perry's Chemical Engineers' Handbook. McGraw-Hill.

Pokrovsky, O.S., Schott, J., 2000a. Forsterite surface composition in aqueous solutions: a combined potentiometric, electrokinetic, and spectroscopic approach. Geochim. Cosmochim. Acta 64, 3299-3312.

Pokrovsky, O.S., Schott, J., 2000b. Kinetics and mechanism of forsterite dissolution at $25^{\circ} \mathrm{C}$ and $\mathrm{pH}$ from 1 to 12 . Geochim. Cosmochim. Acta 64, 3313-3325.

Putnis, A., 2009. Mineral replacement reactions. Rev. Mineral. Geochem. 70, 87-124.

Rimstidt, J.D., Brantley, S.L., Olsen, A.A., 2012. Systematic review of forsterite dissolution rate data. Geochim. Cosmochim. Acta 99, 159-178.

Rosso, J.J., Rimstidt, J.D., 2000. A high resolution study of forsterite dissolution rates. Geochim. Cosmochim. Acta 64, 797-811.

Safari, V., Arzpeyma, G., Rashchi, F., Mostoufi, N., 2009. A shrinking particle shrinking core model for leaching of a zinc ore containing silica. Int. J. Miner. Process. 93, 79-83.

Schott, J., Berner, R.A., 1983. X-ray photoelectron studies of the mechanism of iron silicate dissolution during weathering. Geochim. Cosmochim. Acta 47, $2233-$ 2240.

Sissmann, O., Daval, D., Brunet, F., Guyot, F., Verlaguet, A., Pinquier, Y., Findling, N., Martinez, I., 2013. The deleterious effect of secondary phases on olivine carbonation yield: insight from time-resolved aqueous-fluid sampling and FIBTEM characterization. Chem. Geol. 357, 186-202.

Sissmann, O., Brunet, F., Martinez, I., Guyot, F., Verlaguet, A., Pinquier, Y., Daval, D., 2014. Enhanced olivine carbonation within a basalt as compared to singlephase experiments: reevaluating the potential of $\mathrm{CO}_{2}$ mineral sequestration. Environ. Sci. Technol. 48, 5512-5519.

Stockmann, G.J., Wolff-Boenisch, D., Gislason, S.u.R., Oelkers, E.H., 2011. Do carbonate precipitates affect dissolution kinetics? 1: Basaltic glass. Chem. Geol. 284, 306-316.

Van Herk, J., Pietersen, H.S., Schuiling, R.D., 1989. Neutralization of industrial waste acids with olivine-the dissolution of forsteritic olivine at $40-70^{\circ} \mathrm{C}$. Chem. Geol. 76, 341-352.

Wang, F., Giammar, D.E., 2012. Forsterite dissolution in saline water at elevated temperature and high $\mathrm{CO}_{2}$ pressure. Environ. Sci. Technol. 47, 168-173.

Webb, P.A., Orr, C., 1997. Analytical Methods in Fine Particle Technology. Micromeritics, Norcross, GA.

White, A.F., 1995. Chemical weathering rates of silicate minerals in soils. Rev. Mineral. Geochem. 31, 407-461.

Wogelius, R.A., Walther, J.V., 1992. Olivine dissolution kinetics at near-surface conditions. Chem. Geol. 97, 101-112.

Yoder, H.S., Sahama, T.G., 1957. Olivine X-ray determinative curve. Am. Mineral. 42, 475-491. 